\title{
REVIEW
}

\section{THE BIOSYNTHESIS OF NITRIC OXIDE FROM L-ARGININE. NITRIC OXIDE FORMATION FEATURES AND ITS FUNCTIONAL ROLE IN MITOCHONDRIA}

\author{
G. V. DANYLOVYCH, T. V. BOHACH, Yu. V. DANYLOVYCH
}

Palladin Institute of Biochemistry, National Academy of Sciences of Ukraine, Kyiv; e-mail: danylovych@biochem.kiev.ua

Modern data on biochemical patterns of nitric oxide biosynthesis in mammal cells from L-arginine in normoxic conditions is described. The attention of the authors is given to the results of the recent years on the structure and regulation features isoforms of NO-synthase. The emphasis is put on the latest conception of the compartmentalization of certain isoforms of these enzymes in cells and on the possibility of the directed transport of nitric oxide in the vascular wall. The central place in the review is devoted to issues on the endogenous formation of $N O$ in mitochondria and its potential physiological significance. Our own results on the identification of $N O$ in mitochondria of the uterine smooth muscle, biochemical characteristics of this process and $\mathrm{NO}$ possible role in $\mathrm{Ca}^{2+}$ transport regulation by organelles are presented and discussed.

Key word s: nitric oxide, mitochondria, NO-synthases, cell compartments, calcium, smooth muscle.

I $\mathrm{n}$ foreign scientific literature and, partly, in national periodicals, there are numerous review papers devoted to various aspects of the formation and biological activity of nitric oxide and its derivatives (nitric active forms). In view of this, in the presented article the authors tried to provide general ideas about the biosynthesis regularities and the role of NO in a cell in the most summarized version, primarily focusing on the problems that have become relevant in the last period of research, such as compartmentalization of certain isoforms of NO-synthase in cells and the possibility of directed transport of nitric oxide in the vascular wall. Particular attention is paid to the less highlighted and investigated problem - mitochondria own synthesis of nitric oxide and its possible functional activity in this compartment. Available material relates only to the synthesis of NO from L-arginine in the presence of $\mathrm{O}_{2}$ and does not include important issues on reductase activity in hypoxic conditions and the functioning of the nitric oxide cycle in the mammalian organism. Numerous works by prof. Reutov V. P. and, for example, a review article in Ukrainian are devoted to these problems [1].

Nitric oxide (NO) is a structurally simple low molecular amphiphilic free radical molecule. In biosystems NO has a relatively short time of existence (up to 5 sec depending on microenvironment) and can migrate at short distances from the generation sites what is determined by the rate of oxidation [2]. This limitation of diffusion implies the specificity of NO effect in individual cell compartments due to the colocalization of target proteins with NO sources in a multiprotein complex of signalosomes.

Synthesis of NO in a cell is provided by the family of isoforms of NO-synthase (NOS), which, with the participation of NADPH as an electron source and the presence of $\mathrm{O}_{2}$, carry out a five-electron two-stage oxidation of the L-arginine guanidine group with the formation of NO and L-citrulline [2-7].

NO is an almost universal messenger and regulatory molecule. NO signaling is carried out in three main mechanisms: (1) activation of soluble guanylate

(C) 2018 Danylovych G. V. et al. This is an open-access article distributed under the terms of the Creative Commons Attribution License, which permits unrestricted use, distribution, and reproduction in any medium, provided the original author and source are credited. 
cyclase (sGC) through binding to its heme group (thus forming a $\mathrm{Fe}^{2+}$-nitrosyl complex), which leads to the formation of cGMP, which in turn stimulates protein kinase G, PKG; the concentration of NO required for the activation of sGC is within the range of 80-250 nM [2, 5, 10, 11]; (2) S-nitrosylation: active forms of nitrogen - $\mathrm{NO}^{+}, \mathrm{NO}^{-}, \mathrm{N}_{2} \mathrm{O}_{3}, \mathrm{NO}_{2}$ reversibly nitrosilate thiol groups of target protein cysteins; there is a view that in the cardiovascular system most of the NO effects are mediated precisely by S-nitrosylation and are cGMP-independent $[2,5,8$, 10-12]; (3) the formation of peroxynitrite (ONOO-), primarily due to the diffusion-controlled reaction between NO and superoxide anion $\left({ }^{\circ} \mathrm{O}_{2}^{-}\right)$with subsequent nitration of the tyrosine and tryptophan residues in proteins, leading to the engagement of mitogen-activated protein kinases, protein kinase $\mathrm{C}$ isoforms, transcription factor NF- $\mathrm{\kappa B}$, etc., in the process of signaling [2, 5, 9, 12]. NO targets include an extremely wide range of proteins, including the major metabolic enzymes and transcription factors [2, 4-7]. The termination of NO/sGC/cGMP/PKG direction signal, which is key for the implementation of the functional activity of nitric oxide, is enabled by the family of phosphodiesterases (PDE 5, 6, 9) $[13,14]$.

Nitric oxide affects the flow of numerous cellular processes. Depending on the concentration, it regulates the transcription of genes and the translation of mRNA (by changed of transcriptional factor activity), predetermines and modulates post-translational modifications of proteins (such as nitrosylation, ADP-ribosylation), has cytostatic and cytotoxic properties [15]. The inhibition of potential-dependent $\mathrm{Ca}^{2+}$ channels and the activation of $\mathrm{Ca}^{2+}$-dependent $\mathrm{K}^{+}$channels of the plasma membrane, along with the stimulation of $\mathrm{Ca}^{2+}, \mathrm{Mg}^{2+}$-ATPases of plasmalemma and endo/sarcoplasmic reticulum in a number of objects, including the smooth muscle of the internal organs and vessels, is carried out by S-nitrosylation of functionally important cysteine residues of transport proteins and provides a decrease in $\mathrm{Ca}^{2+}$ concentration in the cytoplasm [2, 8, 16, 17].

NO is a key player in many physiological processes: it regulates the tone and permeability of blood vessels, reduces the aggregation of blood cells and their adhesion to the vascular wall, participates in the functioning of nervous, endocrine, immune systems [2, 13, 18-20].

To date, it has been found that NO modulates energy, metabolic and transport processes in mito- chondria. The inner membrane of mitochondria is an effective target of nitrocompounds, since the enzymes localized therein contain high levels of thiol residues, iron-sulfur centers, heme groups, and the membrane itself is the site of the formation of superoxide anion [13, 21-23]. Nitric oxide is capable of regulating the activity of mitochondria electron transport chain, reversibly suppressing cytochrome $c$-oxidase, and controlling the value of mitochondrial matrix pH [13, 21, 24]. At low nanomolar concentrations NO limits the intensity of respiration and oxidative phosphorylation, which is a physiologically significant reaction $[5,7,25]$. NO regulates $\mathrm{Ca}^{2+}$ homeostasis in mitochondria and, accordingly, $\mathrm{Ca}^{2+}$-dependent processes, primarily the activity of a range of dehydrogenases [26-28]. NO/cGMP-dependent decrease of electric potential on the inner membrane of mitochondria, which influences the intensity of electrophoretic $\mathrm{Ca}^{2+}$-accumulation, is described [5]. NO/cGMP system regulates the synthesis of ATP by mitochondria [4, 5]. Nitric oxide stimulates the biogenesis of mitochondria in tissues of various types and, in particular, increases the expression of sirtuin-1, which together with 5'-AMP protein kinase (AMPK) regulates peroxisome proliferator-activated receptor- $\gamma$ coactivator- $1 \alpha$ (PGC- $1 \alpha)$ which is a regulator of mitochondrial biogenesis [5, 24, 29, 30].

Excessive production of $\mathrm{NO}$ against the background of the intensification of superoxide anion formation in mitochondria is accompanied by the generation of substantive amounts of peroxynitrite, the damage of the components of the electron transport chain, the irreversible depolarization of organelles, and the development of mitochondrial dysfunction, which may be the cause of apoptosis $[5,9,18]$. The reaction between $\mathrm{NO}$ and ${ }^{\circ} \mathrm{O}_{2}^{-}$is considered an important factor in reducing the bioavailability and physiological activity of nitric oxide in mitochondria. Peroxynitrite causes oxidative damage, nitration and S-nitrosylation of biomolecules - proteins [9, 28], lipids, DNA [18, 31], irreversible inactivation of $\mathrm{Mn}^{2+}$-containing superoxide dismutase [32], matrix aconitase [33], and decreases the content of reduced glutathione [12]. Nitrosative stress induced by ONOO- leads to non repair breaks and other DNA damage with subsequent activation of the transcription factor p53 and poly-ADP-ribosopolymerase [31, 34-36]. The examples provided show that both normal functioning and cell death depend to a large extent on the level of NO production and the intensity of the generation of active forms of oxygen precisely in mitochondria [5, 7, 24, 37]. 
Consequently, the unique biological role of NO has for many years attracted the attention of researchers to the problem of regulation of nitric oxide biosynthesis and the relationship between $\mathrm{NO}-\mathrm{mi}$ tochondria entirely due to the extremely important role of the latter in the metabolic and regulatory processes in a cell. A significant part of the presented review is devoted to this important issue as well as to the selected results of the personal research.

NO synthase isoforms. NOS enzyme (EC 1.14.13.39) exists in dimer form built of two identical subunits that are structurally and functionally divided into two main domains: C-terminal reductase and $\mathrm{N}$-terminal oxygenase domains. The reductase domain has a high homology with the cytochrome $\mathrm{P} 450$ reductase and contains binding sites for NADPH, FAD and FMN (for one molecule of each); the oxygenase domain interacts with the prosthetic heme group, the cofactor $\mathrm{BH}_{4}(6(\wedge)$-5,6,7,8-tetrahydrobiopterin) and the substrate L-arginine. There is a calmodulin-binding domain between these two structures (Fig. 1) [3, 38-40].

There are 3 NOS isoforms that differ in structure and functions. Endothelial NOS (eNOS/NOS III, the subunit with a weight of $134 \mathrm{kDa}$ ) and neuronal NOS (nNOS/NOS I, the canonical subunit with a weight of $160 \mathrm{kDa}$ ) are constitutively expressed by $\mathrm{Ca}^{2+}$-dependent enzymes; there is evidence that eNOS can also be activated at low concentrations of
$\mathrm{Ca}^{2+}$ in the medium. Inducible NOS (iNOS/NOS II, the subunit with a weight of $130 \mathrm{kDa}$ ) is expressed in most cells only after being induced by proinflammatory cytokines, bacterial lipopolysaccharides, $\gamma$-irradiation, and its activity is independent of intracellular $\mathrm{Ca}^{2+}$ (activates at the nonphysiologically low cation concentration of about $40 \mathrm{nM}$ ), since calmodulin is firmly bound at the appropriate site due to the specific amino acid sequence of the latter $[4,38]$. Although all three main types of NOS are characterized by high homology, in some cases, each isoform shows somewhat different structural features that correspond to its specific function in vivo (Fig. 1) [4, 18, 38, 41]. The names of the isoforms (endothelial, neuronal) originate from the primary source of the identification and, to a large extent, do not reflect the actual tissue distribution.

nNOS is expressed in central and peripheral neurons, as well as in the epithelial cells of lungs, in skeletal muscle, uterine tissues, stomach, kidneys, pancreas $[4,17,20,42]$. The enzyme is highly conservative, $93 \%$ of amino acid composition in rat and human tissues are identical $[4,43]$. There are several splice variants of $\mathrm{nNOS}$ : $\mathrm{nNOS} \alpha, \mathrm{nNOS} \beta, \mathrm{nNOS} \gamma$, $\mathrm{nNOS} \mu, \mathrm{nNOS}-2[3,6,44]$. $\mathrm{nNOS} \alpha$ and $\mathrm{nNOS} \mu$, which are the most abundant in tissues, contain a PDZ domain on the N-terminus (a sequence of 220 amino acid residues) that can directly interact with PDZ-motifs of other proteins, which determines the

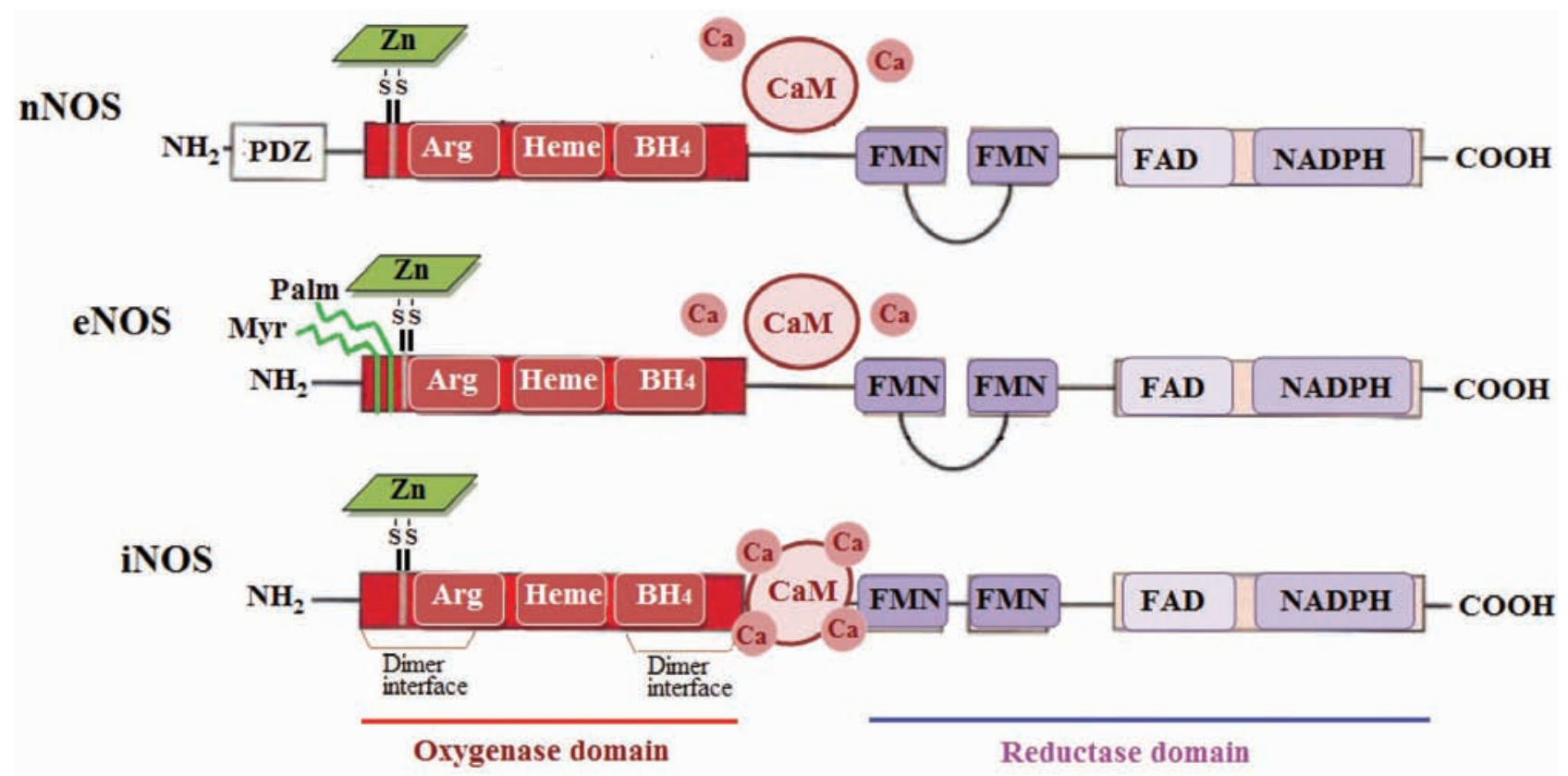

Fig. 1. Domain structure of human nNOS, eNOS and iNOS. The autoinhibitory loop within the FMN regions of nNOS and eNOS are shown 
subcellular localization and enzyme activity [45, 46]. The presence of the PDZ domain is unique for nNOS isoforms [38]. In cardiomyocytes and skeletal muscle, the splice variant of nNOS $\mu$ is expressed. This form of enzyme includes a unique (34 amino acids) insertion between the calmodulin and FMN-binding sites [3, 30, 40, 45, 47]. $\mathrm{Ca}^{2+}$-transport ATPase of the plasma membrane (isoform $4 \mathrm{~b}$ available in the smooth muscle cells) binds in the C-terminal region to the PDZ domain of $n N O S \mu$ and acts as a negative NO synthesis regulator. Also, the interaction of nNOS with the cytosolic part of the adrenergic and glutamate receptors [2, 3, 39], $\alpha$-syntrophindystroglycan complex of skeletal muscle sarcolemma, phosphofructokinase, etc. is shown [2, 38, 39, $48,49]$. In cardiomyocytes, nNOS can bind to the ryanodine receptor and xanthine oxidoreductase on the surface of the sarcoplasmic reticulum [2].

In the N-terminal region of nNOS, a binding site for an 89-amino acid protein PIN (NOS protein inhibitor) was found. PIN inhibits NOS, causing its monomerization. It also suppresses the NADPH-oxidase activity of all three isoforms. The PIN is identified as a light chain of myosin and dynein, which may indicate its alternate role as an axonal transport protein for nNOS [3, 30, 50-52].

The most important functions of nNOS include modulation of the synapse plasticity in CNS, central regulation of blood pressure, the tone of smooth muscles of the internal organs, in particular by generating $\mathrm{NO}$ in the nitrergic nerve endings, control of the blood supply to skeletal muscle fibers $[4,30,39$, 43, 53].

eNOS was first identified in endothelial cells, it controls blood pressure and has vasoprotective, hemostatic and antiatherosclerotic effects. This isoform is found in the tissues of lungs and trachea, cardiomyocytes, platelets, brain neurons, syncytiotrophoblasts and kidney epithelial cells [20]. eNOS expression increases in conditions of hypoxia mediated by the transcription factor HIF, as well as in experimental models of wound healing, post-ischemic states, and in the case of the rise of the vascular wall shear stress, where the transcription factor KLF2 is involved (Kruppel like factor). An increase in vascular pressure may result in a boost of eNOS expression with the involvement of NF- $\kappa \mathrm{B}$ as well [38, 54-56]. The endothelial isoform is localized in caveolae but is also found in the Golgi apparatus and the outer mitochondrial membrane [10, 13, 29, 57]. The caveolar association of eNOS is provided by specific covalent modifications. Initially, a myristic acid is cotranslationally and irreversibly attached to the N-terminal glycine residue. Myristoylated eNOS is directed to the Golgi apparatus, where the N-terminal 2 cysteine residues are palmitoylated (Fig. 1). Acylation enables association with caveolae of the plasma membrane $[3,38,58]$. Interaction with the protein caveolin, the structural-organizing component of caveolae, inhibits the activity of eNOS by sterically blocking the interaction with calmodulin. $\mathrm{Ca}^{2+} / \mathrm{CaM}$ enzyme binding, the interaction with the previously phosphorylated on tyrosine Hsp 90, phosphorylation of Ser-1177 residue, dephosphorylation of Thr- 495 stimulates its activity $[4,10,13]$. Over the years, the list of serine/threonine/tyrosine residues of different domains has been expanded and refined, as well as protein kinases/protein phosphatases, which have a regulatory effect on eNOS (Fig. 2) [13, 39, 59-61]. In particular, activatory phosphorylation is provided by kinase families depending on the nature of the regulatory influence: Akt/PKB, PKA, PKG, AMPK, $\mathrm{Ca}^{2+}$-CaMK II, etc. [3, 4, 9, 17, 62, 63]. This process is triggered by insulin, VEGF, acetylcholine, bradykinin, estrogens, excessive pressure on the endothelium during hypertension, and so on [2, 5, 10]. Agonists of eNOS are ATP, neurotransmitters - acetylcholine and histamine, growth factors (growth factor of vascular endothelium, VEGF), hormones (insulin, 17ß-estradiol [17]), lipids, kinins [2, 5, 10, 13, 17].

Colocalization of the cationic transporter of Larginine (CAT1), eNOS and caveolin-1 in endothelial cells promotes the access of the substrate to eNOS and optimizes the biosynthesis of NO [39, 64, 65].

Cysteine residues are important for eNOS functioning. The reverse $\mathrm{S}$-nitrosylation by the product of the reaction is accompanied by the decrease in enzymatic activity. Two highly conservative cysteine residues of the reductase domain may also be the object of S-glutathionation, which, under oxidative stress conditions, reversibly reduces the enzyme activity and increases the generation of ${ }^{\circ} \mathrm{O}_{2}{ }^{-}$in the reductase domain $[2,4,15,30]$.

Another eNOS and NO cell activity modulator - thrombospondin 1 (TSP1) - has recently been found. This protein appears in the extracellular space during tissue damage and binds to CD47 plasmalemma receptor, which causes a down-regulation of signal transduction from acetylcholine receptors, VEGF, inhibition of eNOS and sGC [13, 15, 66, 67].

iNOS was first detected in macrophages, also identified in lymphocytes, neutrophils, eosinophils, 


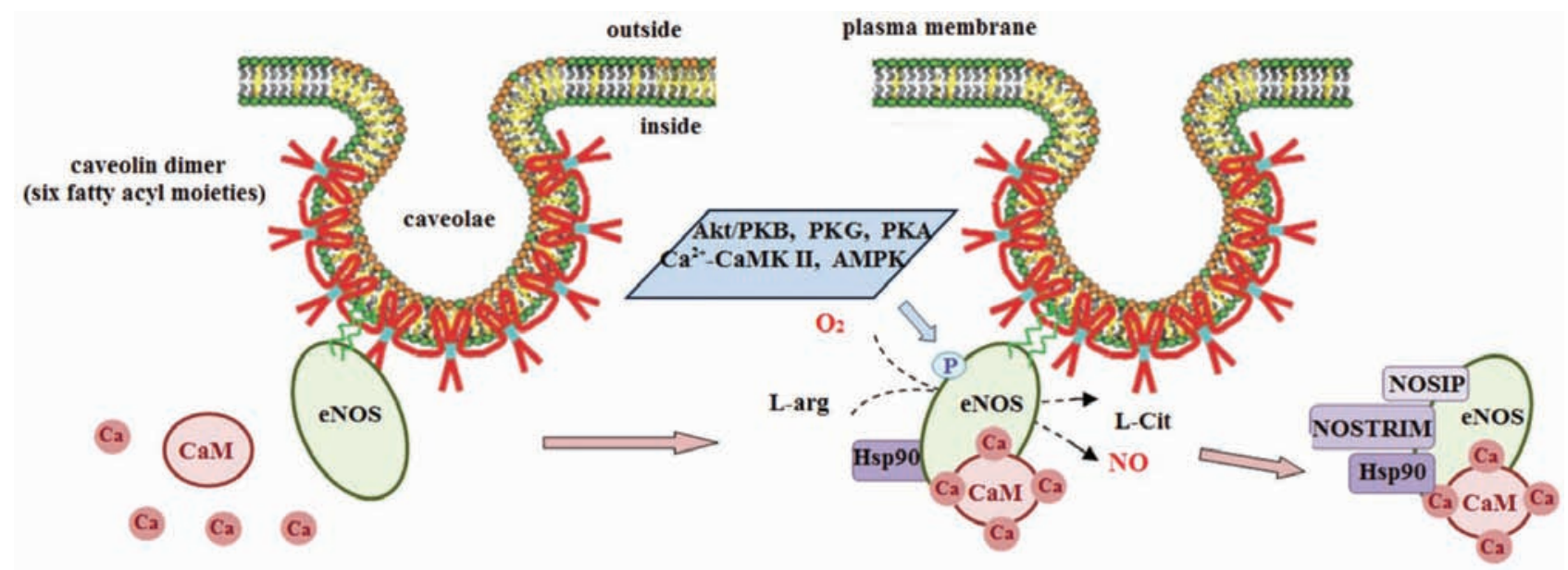

Fig. 2. Regulation of eNOS activity in caveolae. Myristoylation and palmitoylation (depicted as two green lines) target it to the plasma membrane. Interaction with caveolin inhibits eNOS activity, whereas heat shock protein (Hsp) 90 and $\mathrm{Ca}^{2+} / \mathrm{CaM}$ activate its. Akt/PKB, PKG, PKA and others kinases phosphorylate and activate eNOS. eNOS interacting protein (NOSIP) and eNOS traffic inducer (NOSTRIN) participate in translocation of eNOS away from the caveolae to intracellular targets, which results in diminished eNOS activity

it generates NO in large quantities (micromolar concentrations), which has a cytotoxic effect on microorganisms and tumor cells [4, 20,43]. Due to the high affinity of $\mathrm{NO}$ for protein-bound iron, it effectively interacts with iron-sulfur clusters of mitochondrial electron transport chain complexes, cis-aconitase and ribonucleotide reductase, inhibiting these key enzymes of bioenergetics and proliferation in target cells [4, 39, 43]. Nitric oxide produced by macrophages in ultrahigh concentrations also causes single-strand breaks and fragmentation of DNA [4, $18,43]$. iNOS expression is initiated by such proinflammatory cytokines as TNF- $\alpha$, INF- $\gamma$, IL- $1 \beta$, bacterial lipopolysaccharides, and shortwave radiation. This process is controlled by the transcription factor NF- $\kappa \mathrm{B}$ and JAK/STATs signaling pathway $[2,5,20$, 43, 59].

The compartmentalization of various isoforms of NO-synthase in cells and the biochemical features of the action of nitric oxide in different compartments are clearly illustrated in the case of cardiomyocytes [25]. The molecular basis for the opposite action of NO is the selective interaction of eNOS and nNOS with caveolae and sarcoplasmic reticulum. In cardiomyocytes, eNOS is localized in caveolae of sarcolemma and T-tubules, where it is associated with a specific for myocytes protein caveolin-3 $[3,9,13,58,68]$. The colocalization of eNOS with $\beta$-adrenergic receptors and $\mathrm{Ca}^{2+}$ channels results in $\mathrm{Ca}^{2+}$-dependent eNOS-generated production of NO, which remains within the diffusion distance from its molecular targets. Suppressing, probably by direct nitrosylation, the activity of L-type $\mathrm{Ca}^{2+}$ channels in caveolae, nitric oxide limits the flow of $\mathrm{Ca}^{2+}$ to the myoplasm, protecting cardiomyocytes from calcium overload. Such eNOS location allows NO to inhibit $\beta$-adrenergic stimulation and inotropic effects of catecholamines. nNOS immunoprecipitates with ryanodine receptors - $\mathrm{Ca}^{2+}$ channels of sarcoplasmic reticulum [9, 13, 39, 69]. NO generated by this isoform, possibly also by direct nitrosylation, activates channels responsible for $\mathrm{Ca}^{2+}$ release from reticulum, which stimulates actomyosin interaction and regulates the cyclic contractile activity of the myocardium (sarcoplasmic reticulum consistently accumulates and releases $\mathrm{Ca}^{2+}$ in immediate proximity to myofilaments). Localized in the myoplasm, iNOS is transiently expressed in the myocardium during the immune response to stress or under pathophysiological conditions, such as ischemia-reperfusion, sepsis, heart failure. NO produced by this isoform also stimulates the release of $\mathrm{Ca}^{2+}$ from the sarcoplasmic reticulum through ryanodine-sensitive channels [2, 7, 9, 13].

Macrophages have both inducible and constitutive NOS [70, 71]. Endothelial cells, which have a constitutive eNOS, actively express iNOS during the action of proinflammatory cytokines $[13,17]$.

The overwhelming majority of experimental data suggests the existence of a special NOS iso- 
form - mtNOS in the mitochondria, which is a splice variant of $n N O S-\alpha$. mtNOS-generated NO provides a reciprocal regulation between NO biosynthesis in this compartment and the concentration of intramitochondrial $\mathrm{Ca}^{2+}$, L-arginine, $\mathrm{pH}, \mathrm{O}_{2}$ partial pressure, and the oxidation-reduction state of mitochondria [7, 21, 29, 30, 35, 68].

Besides the specific spatial localization in cells of different NOS isoforms with defined functions, there is also a phenomenon of directed and regulated NO transport in the vascular wall - the so-called "myoendothelial gap junction" or "myoendothelial corridor". Being synthesized in eNOS in the endothelium, nitric oxide diffuses to smooth muscle syncytia, activating sGC in myocytes and nitrosylating target proteins. It turned out that this process of paracrine regulation is controlled, and there is a myoendothelial gap junction located between the two tissues. It facilitates the interaction between the endothelium and smooth muscle in small vessels [2, $13,15,25]$. In the "corridor" eNOS, sGC and other proteins are colocalized, that limits the diffusion of NO and reduces the intensity of the action of oxygen active forms as its scavengers. Myoendothelial junction contains a significant amount of hemoglobin, which interacts affinitively with nitrogen oxide. In the reaction with NO, oxyhemoglobin forms methemoglobin and nitrate anion. Methemoglobin is reduced by cytochrome b5-reductase. This mechanism is able to limit the bioavailability of NO in the vascular wall [2, 13, 15, 25, 72]. Connexin hemichannels Cx37, Cx40 and Cx43 are an important structure localized in the myoendothelial junction [73, 74]. During the action of catecholamines on the vascular smooth muscle cells, the concentration of inositol 1,4,5-trisphosphate (IP3), which diffuses into the endothelium following the concentration gradient, increases. S-nitrosylation with nitric oxide activates the mentioned channels. IP3 causes the growth of $\mathrm{Ca}^{2+}$ concentration in the endothelial cells, causing the activation of $\mathrm{Ca}^{2+}$-dependent S-nitrosoglutathione reductase, which results in the denitrosylation and closing of the connexin hemichannels. In addition, these mechanisms provide the $\mathrm{Ca}^{2+}$-dependent synthesis of $\mathrm{NO}$ in the endothelium in response to stimulation of $\alpha 1$-adrenergic receptors in smooth muscle cells $[15,72]$.

NO biosynthesis consists of two consecutive monooxygenase reactions of L-arginine oxidation, 1.5 moles of NADPH and 2 moles of $\mathrm{O}_{2}$ are consumed to form 1 mole of L-citrulline. This process involves the initial hydroxylation of L-arginine with the formation of $\mathrm{N}^{\mathrm{G}}$-hydroxy-L-arginine, which also acts as a substrate for NOS, the following oxidation is accompanied by the formation of L-citrulline and NO $[3,4,38,40]$.

Electron transfer is carried out from the reductase domain of one subunit to the oxygenase domain of another (Fig. 3). The monomers of all isoforms are not able to bind $\mathrm{BH}_{4}$ and $\mathrm{L}$-arginine and do not catalyze the formation of L-citrulline/NO. The isolated reductase domain is capable of transferring electrons from NADPH through flavin rings to artificial substrates cytochrome c and ferricyanide. This ability also persists in the nNOS monomer, indicating that the transport of electrons does not depend on the dimer structure. At the same time, the dimerized oxygenase domain oxidizes $\mathrm{N}^{\mathrm{G}}$-hydroxy-L-arginine. Thus, the two domains perform catalytically different functions $[3,40]$.

The binding of calmodulin controls the electron transport from the reductase to the oxygenase domain, as well as to the reductase domain [3, 38]. Dependency on $\mathrm{Ca}^{2+}$ is the only fundamental difference between constitutive and inducible isoforms, which is due to the complex formation between $\mathrm{Ca}^{2+}$ and calmodulin. Enzymes are not active at a $\mathrm{Ca}^{2+}$ concentration of about $100 \mathrm{nM}$; nNOS and eNOS are stimulated with an increase in the level of intracellular $\mathrm{Ca}^{2+}$ : there is a semi-maximal activity at 200$400 \mathrm{nM}$, the maximum activity occurs at about $500 \mathrm{nM}$ of $\mathrm{Ca}^{2+}[4,43]$. The noted feature of the constitutive isoforms may also be associated with the functioning of the autoinhibiting sequence located in their FMN binding site, but not found in the iNOS. nNOS and eNOS contain 40-50 amino acids in the FMN subdomain, which form an autoinhibitory loop that blocks the interaction with calmodulin at low $\mathrm{Ca}^{2+}$ concentrations and inhibits the transport of electrons from FMN to heme in the absence of $\mathrm{Ca}^{2+}$ / calmodulin [3, 39, 41, 75].

Heme is the only coenzyme absolutely necessary for the formation of the active dimer of constitutive isoforms, but also plays a significant role in iNOS dimerization. With the help of X-ray crystallography, it was found that heme binds to enzymes through a proximal cysteine-thiolate ligand $[3,38$, 40, 76]. Formation of this bond is a key step in the process of dimerization. The investigation of the fluorescence dynamics of nNOS-bound flavins revealed that the heme prosthetic group is also important for the interaction between the reductase and oxygenase domains (Fig. 3). 


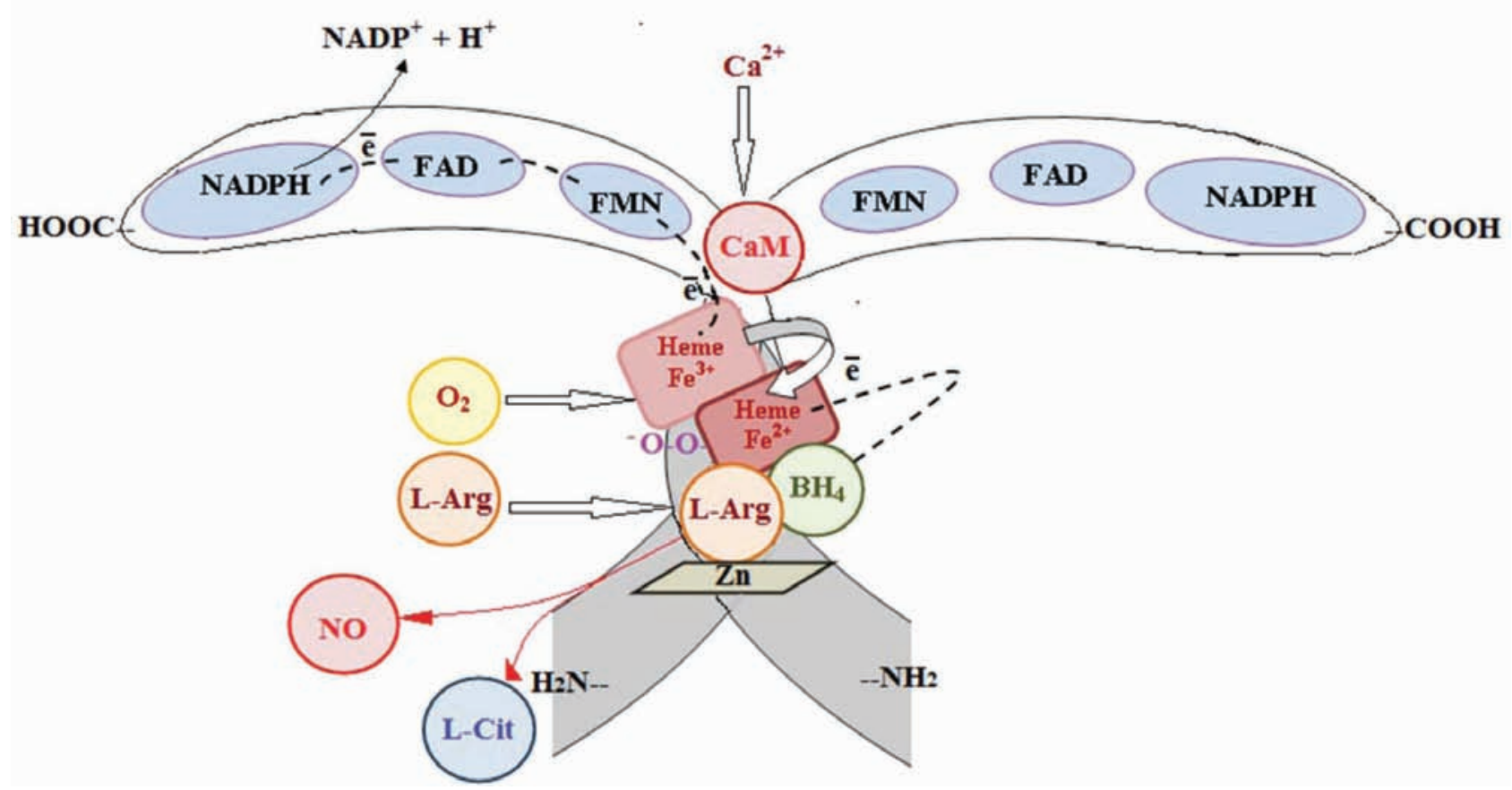

Fig. 3. Functionally active NOS homodimer. The mutual location of coenzymes is schematically illustrated, the binding sites of $\mathrm{O}_{2}$ and L-arginine are marked. The direction of electron transport (two electrons) from $\mathrm{NADPH}$, the dotted line, and the activation process of $\mathrm{O}_{2}$ can be seen

The results of the crystallographic analysis indicate that the localization of $\mathrm{BH}_{4}$ is in the plane of NOS native dimer [38, 76]. Constitutive isoforms dimerize in the absence of $\mathrm{BH}_{4}$, while the iNOS requires its presence. NOS association in the active dimer includes an interaction with $\mathrm{BH}_{4}$, which helps to form a specific "pocket" that contains binding sites for heme and L-arginine [40, 76]. The close proximity of $\mathrm{BH}_{4}$ to heme, as well as flavins in the domain-domain plane, indicates the possible role of tetrahydrobiopterin in the transport of electrons. With the help of EPR-spectroscopy, it was shown that $\mathrm{BH}_{4}$ transports electrons in the oxygenase domain, providing optimal for L-arginine oxidation redox state of the iron of the heme prosthetic group. In this reaction, a trihydrobiopterin radical is formed, which is then reduced by the flavins of the reductase domain. When the availability of $\mathrm{BH}_{4}$ becomes limited, electron transfer from the flavins turns to be not associated with L-arginine oxidation, $-\mathrm{Fe}^{2+}$ O-O-complex of the heme dissociates, and superoxide anion is produced in the oxygen domain [3, $13,77,78]$. The intensity of NO formation is closely correlated with intracellular $\mathrm{BH}_{4}$ concentration, in particular, endothelial dysfunction is accompanied by the decrease in the level of reduced $\mathrm{BH}_{4}$ in en- dothelial cells [2, 17, 79]. The intracellular level of $\mathrm{BH}_{4}$ is regulated by the activity of its biosynthesis de novo and controlled by GTP-cyclohydrolase [4, $35,77,80,81]$.

All of the NOS isoforms contain a Zn-cysteine cluster (Zn-Cys4), which ensures the stabilization of the dimer, its releasing converts the active enzyme into a monomer without catalytic activity [4, 76, 82].

NOS substrate, L-arginine, is synthesized in the urea cycle, and also comes into cells from the blood plasma [2]. In plasmalemma, transporters for cationic amino acids CAT1, CAT2a (smooth muscle cells of vessels) and CAT2b (cardiomyocytes) that transfer L-arginine to cytosol are identified [2, 43, 83, 84]. $K_{\mathrm{m}}$ for L-arginine of transporters reaches $100-150 \mu \mathrm{M}$, which corresponds to its concentration in plasma [65].

$\mathrm{L}$-arginine is a cationic amino acid, which is involved in a range of physiological processes: a necessary precursor of L-ornithine, L-proline, polyamines, agmatine, creatine, proteins [85, 86]. L-arginine is metabolized by several enzymes: arginine/ glycine aminotransferase, arginine decarboxylase, NOS, arginase I and II [2, 87, 88]. L-arginine concentration in the plasma of mammals and humans is $100-200 \mu \mathrm{M}$, in pathological conditions it can be 
reduced to $60 \mu \mathrm{M}$, and in cytosol - to $0.1-1 \mathrm{mM}$ (norma) $[65,87,89]$. On the other hand, the Michaelis constant for L-arginine of eNOS is about $3 \mu \mathrm{M}$ [90]. Endothelial cells do not depend on L-arginine inflow from the extracellular medium because they can effectively convert L-citrulline into L-arginine, as well as obtain L-arginine via proteolysis. Thus, the availability of the substrate is never a limiting factor for the functioning of the NOS in normal conditions. However, an excess of extracellular L-arginine activates NOS or stimulates the synthesis of NO, despite the presence of such intracellular L-arginine concentrations that provide maintaining of maximum NOS activity based on the values of $K_{\mathrm{m}}$. This phenomenon has been called the "arginine paradox" [17, 65, 87, 91], which, in addition to the above, underlies the positive therapeutic effect of $\mathrm{L}$-arginine injection in patients with cardiovascular pathologies. The reason for this phenomenon is seen in competition for the arginase substrate, as well as in the substantial increase in the content of endogenous NOS inhibitors (first of all of the asymmetric dimethylarginine) during the mentioned diseases [65, 85-87].

Arginase hydrolyzes L-arginine to ornithine and urea. In mammalian cells, two types of arginases are identified, which are encoded by different genes. Arginase I is localized in the cytoplasm, while arginase II is a mitochondrial enzyme [2, 88, 92]. $\mathrm{N}^{\mathrm{G}}$-hydroxy-L-arginine, the intermediate product of NO synthesis, is a competitive reversible inhibitor of arginase $[85,87,88,91,93,94]$. The arginase affinity to L-arginine is three orders of magnitude lower $\left(K_{\mathrm{m}}=1-5 \mathrm{mM}\right)$ than for NOS $\left(K_{\mathrm{m}}=2-20 \mu \mathrm{M}\right)$, but the maximum activity $\left(V_{\max }\right)$ is 1000 times higher for arginase than for NOS [65, 85-88, 91]. Endothelial cells express arginase, which can compete with eNOS for L-arginine, and in case of its high activity, deplete eNOS of its substrate [5].

The increase in expression of arginase with the subsequent weakening of NO synthesis during cardiovascular diseases is shown, while pharmacological inhibition of arginase improves NO production. In addition, arginase can inhibit NO generation by iNOS through the urea formation [85, 87].

Another reason for the "arginine paradox" may be the growth of the content of the endogenous NOS inhibitor - the asymmetric dimethylarginine, the product of the enzymatic degradation of proteins, which contain arginine methylated residues. Its concentration in plasma rises during endothelial dysfunctions and cardiovascular diseases [2, 5, 83,
88] and may be the effect of increased angiotensin II level in such patients [95].

Products of NO-synthase reaction. nNOS and eNOS can form not only NO, but also ${ }^{\circ} \mathrm{O}_{2}$. These products react with each other to form $\mathrm{ONOO}^{-}[3$, 38]. The possibility of two products formation by constitutive isoforms of NOS is a consequence of certain differences in the functioning of the two subunits. nNOS purified dimer consists of one $\mathrm{BH}_{4}^{-}$ binding subunit and one free from $\mathrm{BH}_{4}$ unit due to the different affinity of certain sites to the cofactor and to the phenomenon of negative cooperativity, therefore only one of them will accept $\mathrm{BH}_{4}$ in a wide range of its concentrations (up to $1 \mu \mathrm{M}$ ) [38]. This is important for the result of the catalytic reaction, because NOS functions exclusively as NO-synthase only at a high content of $\mathrm{BH}_{4}$. A model has been proposed in which ${ }^{\circ} \mathrm{O}_{2}{ }^{-}$is produced at tetrahydrobiopterin concentrations which are less than $10^{-9} \mathrm{M}$, peroxynitrite is formed at $10^{-9}-10^{-6} \mathrm{M}$ concentrations of the latter, and nitric oxide is synthesized above $10^{-6} \mathrm{M} \mathrm{BH}_{4}$ [96, 97]. Consequently, in conditions of lack of this cofactor, NOS is able to produce ${ }^{\circ} \mathrm{O}_{2}{ }^{-}$or $\mathrm{H}_{2} \mathrm{O}_{2}$. This feature is essential for endothelial dysfunction; in particular, atherogenesis is accompanied by the decrease in the content of reduced $\mathrm{BH}_{4}$ during the action of oxidized lipoproteins, resulting in the reduction in the intensity of NO formation and increased production of other active oxygen metabolites. In addition, $\mathrm{BH}_{4}$ can act as a trap for superoxide anion. That is why $\mathrm{BH}_{4}$ therapy is considered as a perspective approach to restoration of NO bioavailability in vascular wall $[18,35,68,79]$.

At low concentrations of L-arginine or its absence, the constitutive NOS, primarily nNOS, also catalyze one-electron oxygen reduction with the formation of ${ }^{\circ} \mathrm{O}_{2}{ }^{-}$and $\mathrm{H}_{2} \mathrm{O}_{2}$, which may be explained by the lack of interfacing between electron transport in the enzyme and the oxidation of L-arginine guanidine group [38].

One of the major catalytic differences between NOS isoforms is the rate of NADPH oxidation. When there is lack of substrate, nNOS continues to transport electrons to heme and oxidize NADPH with high speed, while eNOS and iNOS perform it much slower. The fact is that nNOS heme iron has a significantly higher reduction potential than iNOS; the latter should first bind the substrate and $\mathrm{BH}_{4}$ to achieve the same value of this parameter [38].

At saturating concentrations of L-arginine and subsaturating concentrations of $\mathrm{BH}_{4}, \mathrm{NO}$ and 
' $\mathrm{O}_{2}{ }^{-}$are simultaneously produced in $\mathrm{BH}_{4}$-containing and $\mathrm{BH}_{4}$-free subunits, respectively. These two compounds form $\mathrm{ONOO}^{-}$, whose content will also be determined by the level of reduced glutathione and the activity of superoxide dismutase [38].

Considering the central role of mitochondria in energy maintaining of cell functioning, in determining its fate under endogenous and exogenous stress influences, and also taking into account modern concepts of mitochondria as a key element in biochemical processes of endothelial dysfunction during cardiovascular diseases, type II diabetes, neurodegenerative pathologies etc. ("mitochondrial diseases"), considerable attention in the modern literature is given to the problem of the relationship: NO - mitochondria. Nitric oxide has a leading role in regulating the functional activity of mitochondria, which, on the one hand, contain systems of their own NO biosynthesis, and on the other hand, are an effective target for active nitrogen forms. It is possible that NO is a key link in maintaining the optimal concentration of $\mathrm{Ca}$ ions, both in the myoplasm and in the mitochondrial matrix. There is evidence that low physiological NO concentrations can have a protective effect on mitochondria, in particular, to prevent excessive generation of active forms of oxygen [5, 9, 18, 69].

Identification and biochemical properties of mtNOS. It is known that mitochondria are the primary cell targets for NO. There is no doubt that biochemistry and molecular physiology of mitochondria, which combine the processes of oxygen consumption, oxidative phosphorylation, lipid catabolism, heme biosynthesis, maintenance of $\mathrm{Ca}^{2+}$ homeostasis, production of active forms of oxygen and apoptosis, are largely controlled by nitrogen oxide [26].

The first publications of the results on mitochondria own NO production began to appear approximately in 1995. In 1997 P. Ghafourifar and C. Richter demonstrated the existence of functionally active mitochondrial NOS (common abbreviation - mtNOS) in rat liver mitochondria. The enzyme in the presence of L-arginine formed $\mathrm{NO}$ and L-citrulline and was $\mathrm{Ca}^{2+}$-dependent. L-arginine analogs, $\mathrm{N}^{\mathrm{G}}$-monomethyl-L-arginine (L-NMMA) and $\mathrm{N}^{\mathrm{G}}$-nitro-L-arginine (L-NA) inhibited the enzyme. mtNOS activity was associated with the inner mitochondrial membrane. In intact energized by succinate mitochondria, the enzyme was constitutively active, it depended on the intensity of mitochondrial respiration and was under the control of the membrane potential [98].

In 1998, C. Giulivi and A. Boveris with co-authors [99] showed NO production in rat liver mitochondria with direct, reliable, precision independent methods: electron-paramagnetic resonance, using spin trap technique (dithiocarbamate derivatives) and two-wavelength spectrophotometry of oxidized hemoglobin. Investigations were performed on purified preparations of mitochondria (intact, permeabilized organelles, submitochondrial particles) and the crude fraction of mtNOS; an apparent $K_{\mathrm{m}}$ for L-arginine was also determined, namely 5-7 $\mu \mathrm{M}$, which was close to that of nNOS [99-101]. The authors concluded that the greatest activity of the enzyme is inherent to the inner mitochondrial membrane. It was assumed that endogenously synthesized NO may affect the energetics of organelles, the consumption of $\mathrm{O}_{2}$ and the formation of free oxygen radicals.

In studies on permeabilized with digitonin myocytes of the heart ventricle, using DAF-2 (4,5-diaminofluorescein diacetate) NO-sensitive fluorescent probe and the specific for mitochondria dye $\mathrm{Mi}-$ toTracker Red CMXRos, E. Dedkova and L. Blatter showed that in the presence of L-arginine and the increment of $\mathrm{Ca}^{2+}$ concentration in the cytoplasm, there is a dose-dependent rise in NO production in mitochondria. The collapse of the membrane potential in the presence of the protonophore CCCP, the blockage of $\mathrm{Ca}^{2+}$-uniporter of the inner mitochondrial membrane with Ru360, the use of rotenone or antimycin $\mathrm{A}$ - the inhibitors of electron transport chain, in combination with oligomycin resulted in inhibition of NO synthesis in mitochondria [68].

There is evidence that energized mitochondria are capable of producing NO in the absence of NADPH, L-arginine and exogenous $\mathrm{Ca}^{2+}$ in incubation medium [7, 42, 101]. The intramitochondrial concentration of NADPH is $1.04-1.78 \mathrm{mM}$, which significantly exceeds the respective value of $K_{\mathrm{NADPH}}$ for mtNOS $(0.1-1 \mu \mathrm{M})$ [98]. The concentration of Larginine in the mitochondrial matrix corresponds to 150-310 $\mu \mathrm{M}$ and is substantially higher than $K_{\mathrm{m}}$ for L-arginine (5 $\mu \mathrm{M}$ for liver mitochondria [99, 102], $35 \mu \mathrm{M}$ - for cardiomyocytes). Thus, the concentrations of L-arginine, $\mathrm{Ca}^{2+}$ and NADPH are not ratelimiting NO synthesis factors in mitochondria [7, 92, 102]. The lack of L-arginine in the matrix and the corresponding decrease in mtNOS activity may be due to the increased activity of arginase II in mitochondria, which competes with the enzyme for sub- 
strate [86, 88]. In the inner membrane of mitochondria, a basic amino acid transporter (SLC25A29) was identified that functions as a uniporter and provides access of L-arginine to mitochondrial arginase II and NOS $\left(K_{\mathrm{m}}=0.42 \mathrm{mM}\right)[92,103]$.

Apparent $K_{\mathrm{m}}$ for $\mathrm{O}_{2}$ of mtNOS of cardiomyocytes is $40 \mu \mathrm{M}$. Thus, under physiological conditions, when the concentration of $\mathrm{O}_{2}$ is within 5-20 $\mu \mathrm{M}$, the mtNOS activity does not reach the maximum values [19].

When there was lack of $\mathrm{L}$-arginine or $\mathrm{BH}_{4}$ in the conditions of stimulation of $\mathrm{Ca}^{2+}$ accumulation by organelles, NO formation was significantly lower, but at the same time, there was a rise in the production of oxygen active forms [68].

Conducted by us experiments on freshly isolated rat uterine myocytes, using a fluorescent dye DAF-FM (this probe was less sensitive to the action of a laser light), MitoTracker Orange CM- $\mathrm{H}_{2}$ TMRos and the method of laser confocal microscopy, demonstrated the colocalization of these dyes and, accordingly, the possibility of NO formation in mitochondria [104] (Fig. 4).

Liver mtNOS, solubilized and purified by affinity chromatography method, synthesized 250$350 \mathrm{nmol}$ of $\mathrm{NO} / \mathrm{min} / \mathrm{mg}$ of a protein, $K_{\mathrm{m}}$ for Larginine was $3 \mu \mathrm{M}$, the enzyme was inhibited by L-NMMA. A detailed analysis of the amino acid composition of mtNOS found that the protein structure corresponds to the nNOS primary sequence [105].

The identity of mtNOS and nNOS also proves the results on the inhibition of the enzymatic activity: a relatively specific blocker of nNOS (4S)-N-(4amino-5[aminoethyl] aminopentyl)-N'-nitroguanidine and the calmodulin antagonist W-7 inhibited the formation of NO in the mitochondria of cardiomyocytes, while the inhibitors eNOS - 1-N5-(1iminoethyl)ornithine (1-NIO) and iNOS - N-(3-aminomethyl) benzylacetamidine, 2HCl (1400W) were ineffective [68].

Currently, mitochondrial localization of NOS is reliably shown in various mammalian organs and tissues: liver [102, 105], heart [9, 18, 68], brain [103], kidneys [106], skeletal muscle diaphragm [6, 107] and thymus [108].

To sum up, experimental data indicates that mtNOS is continuously expressed in mitochondria, it is a membrane-bound enzyme and its biochemical properties resemble constitutive NOS, particularly the neuronal isoform.
Structure and regulation of mtNOS. The enzyme is a splice variant of a full-chain $n N O S \alpha$, different from the already identified, with a molecular weight of $144 \mathrm{kDa}$. It has two post-translational modifications: N-terminal myristoylation of Thr or Ser and C-terminal phosphorylation of Ser-1412 residue [9, 18, 28, 42, 59, 100, 109]. Immunocolocalization of mtNOS with mitochondrial markers (succinate dehydrogenase, cytochrome $c$-oxidase) further strengthens the evidence of its placement precisely in the inner mitochondrial membrane. The mtNOS myristoylation is necessary to direct the enzyme into mitochondria or to anchor it to the membrane. The phosphorylation of the C-terminal Ser residue regulates mtNOS activity [7, 30, 42, 109].

Immune-electron microscopy methods and immunoprecipitation techniques show the interaction of mtNOS via the PDZ domain with the subunit $\mathrm{V}_{\mathrm{a}}$ of cytochrome $c$-oxidase, which is dependent on $\mathrm{Ca}^{2+}$. Other studies have found that proteins of the complex I of the electron transport chain immunoprecipitate with intramitochondrial NOS [7, 19, 21, 59, 109, 110].

mtNOS activity is maximal during optimal electron transport chain work, specifically complex I, which serves as a source of electrons for the functioning of the enzyme; the inactivation of complex I limits mtNOS activity [111, 112].

The rate of NO formation depends on the metabolic state of mitochondria. The current concept of metabolic states of mitochondria and respiratory control is based on the rate of $\mathrm{O}_{2}$ absorption by isolated organelles. The high rate of $\mathrm{O}_{2}$ consumption and ATP production is observed in the case of adding respiratory substrates and ADP during the metabolic state 3. The absence of ADP causes low rate of $\mathrm{O}_{2}$ absorption, ATP is not synthesized, and the inner mitochondrial membrane is hyperpolarized (metabolic state 4) [113].

During the transition from the state 4 to the state 3, NO synthesis in mitochondria slows down by almost $60 \%$. NO release exponentially depends on the value of the inner membrane electrical potential [114]. Agents that reduce or destroy the membrane potential (uncouplers and protonophores) diminish NO synthesis, while the addition of oligomycin, which hyperpolarizes the inner mitochondrial membrane, leads to the generation of maximum amounts of NO. Thus, it is possible to talk about the regulation of mtNOS activity by membrane potential within its physiological values [7, 101]. 

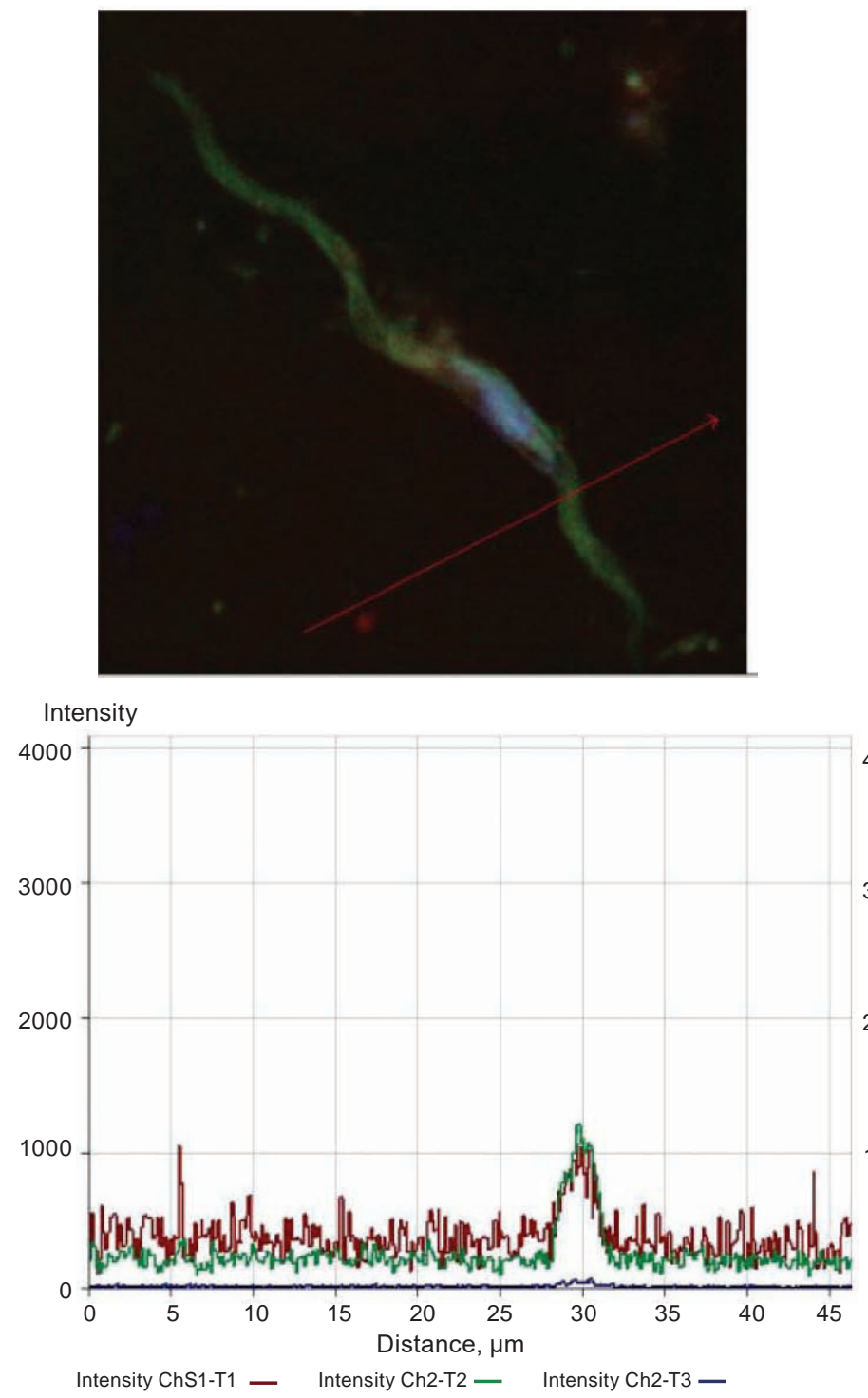
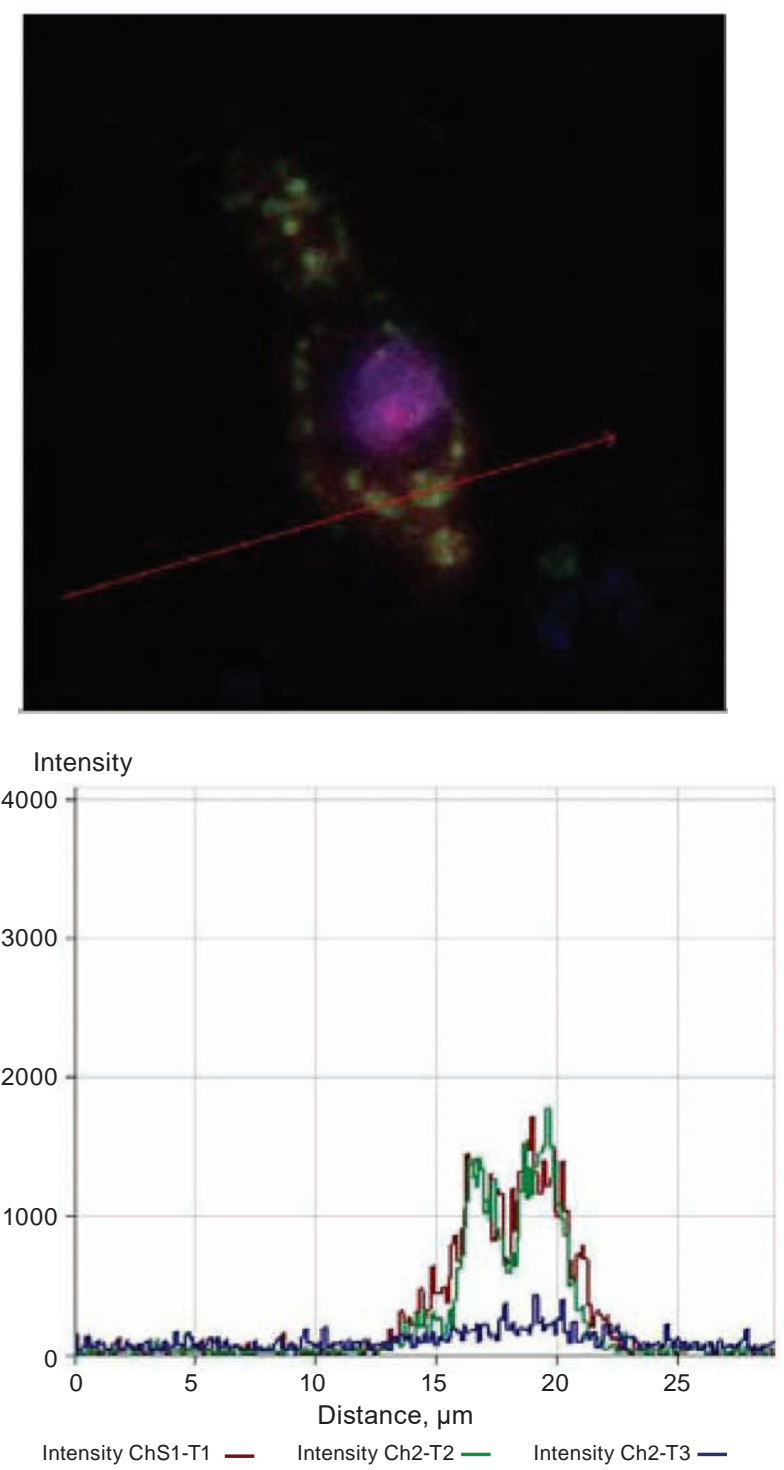

Fig. 4. Variants of colocalization of DAF-FM and MitoTracker Orange CM-H $\mathrm{H}_{2}$ TMRos fluorescent probes in two myocytes, immobilized and spread on a treated with poly-L-lysine glass surface. The results of the identical distribution of dyes of arbitrary optical cell sections are presented: red color - MitoTracker Orange $\mathrm{CM}-\mathrm{H}_{2}$ TMRos (500 nM), green - DAF-FM (10 $\left.\mathrm{MM}\right)$, blue - specific to the nucleus dye Hoechst $33342(50 \mu M)$

Recently, using the panel of modifiers of the electron transport chain on the fraction of isolated mitochondria of the rat uterine smooth muscle, we obtained the following results [115]. In the absence of exogenously added respiratory substrates, isolated mitochondria produce $\mathrm{NO}$ at the expense of internal reserves; this process is significantly enhanced under conditions of mitochondrial energizing and their inner membrane hyperpolarization together with the addition of respiratory substrates or oligomycin (Fig. 5). Instead, in the state of effective oxidative phosphorylation (state 3), NO synthesis decreases. Inhibition of certain complexes of the respiratory chain by rotenone and antimycin A, as well as dissipation of the electrochemical gradient after the addition of protonophore CCCP, leads to the same consequences. Biosynthesis of nitric oxide by smooth muscle mitochondria is a $\mathrm{Ca}^{2+}$-dependent process since it is inhibited by ruthenium red $-\mathrm{a} \mathrm{Ca}^{2+}$-uniporter blocker of their inner membrane (Fig. 5).

It should be noted that the decrease of NO production during the transition from the state 4 to the state 3 is the opposite of what one would expect from the slight matrix acidification and the $\mathrm{pH}$ dependency on the activity of mtNOS. The dependency of NO products on the internal mitochondrial $\mathrm{pH}$ (in the 


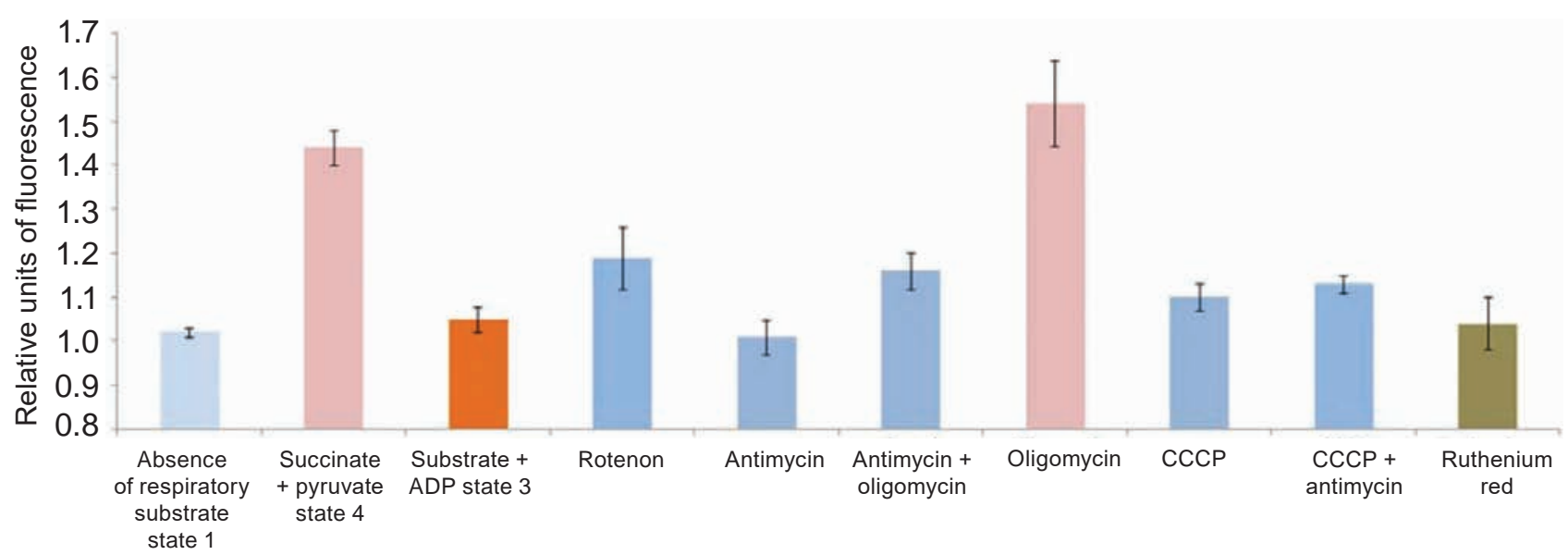

Fig. 5. Dependency of mtNOS activity on the presence in mitochondria of respiratory substrates, $0.5 \mathrm{mM}$ $A D P$, electron transport chain inhibitors (5 $\mu$ M of rotenone, $1 \mu \mathrm{g} / \mathrm{ml}$ of antimycin $\mathrm{A}, 1 \mu \mathrm{g} / \mathrm{ml}$ of oligomycin), $10 \mu \mathrm{M}$ of the protonophore CCCP and the inhibitor of $\mathrm{Ca}^{2+}$ transport to mitochondria - $10 \mu \mathrm{M}$ ruthenium

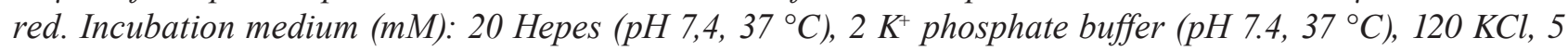
pyruvate, 5 succinate, 0.05 L-arginine, $0.1 \mathrm{Ca}^{2+}, 0.01 \mathrm{NADPH}, 0.01$ tetrahydrobiopterin, aliquot of the mitochondria fraction contained $100 \mu \mathrm{g}$ of protein; 1 on the axis of "relative units of fluorescence" - endogenous synthesis of nitric oxide by isolated mitochondria, $M \pm m, n=5$; the results of flow cytometry, according to the changes in fluorescence of NO-sensitive probe DAF-FM. States 1, 3, 4-mitochondria respiration states by Chans, particularly: 1 - almost no respiration, 4 - low respiration, mitochondria hyperpolarization, high energy state; 3 - effective respiration, complete conjugation between respiration and oxidative phosphorylation, ATP synthesis

range of 5.5-8.5) has a bell-shaped character with a maximum point at $\mathrm{pH} 7.4$ [101]. Taking into account matrix $\mathrm{pH}$ value at about 7.5 in the state 3 and about 7.8 in the state 4 [116], mtNOS activity should be higher in the first case. These results indicate that a larger synthesis of NO in the state 4 is not associated with $\mathrm{pH}$ changes. There is a view that mtNOS activity is regulated precisely by an electric, not a proton, component of the membrane potential on the inner mitochondrial membrane [101, 117].

Therefore, our results clearly demonstrate and correspond with the conceptions that nitric oxide biosynthesis by mitochondria depends significantly on their level of energy, the magnitude of the electrical potential and the intensity of the input of the exogenous $\mathrm{Ca}^{2+}$ into matrix.

Functional role of $\mathrm{NO}$ in mitochondria. Stationary concentration of NO in the mitochondrial matrix is measured using microsensor technology in the nanomolar range, while intact organelles are capable of producing NO at significantly higher micromolar concentrations. This indicates that a substantial part of the formed nitric oxide reacts with mitochondrial targets: ${ }^{\circ} \mathrm{O}_{2}^{-}$, heme and protein thiol groups [7, 102].
In mitochondria, nitric oxide can perform several key functions: inhibition or induction of biogenesis, respiration control and oxidative phosphorylation; NO affects the $\Delta \psi$ of the inner mitochondrial membrane, and regulates the activity of $\mathrm{Ca}^{2+}$ transport systems, the functioning of the permeability transition pore (PTP), etc. [24, 26, 29, 30, 59, 118]. Moreover, NO controls the expression of several Krebs cycle enzymes [47]. The key role of mtNOS may be regulation of the processes of cell ATP synthesis. Mitochondrial NO is involved in the mechanisms, which are at the basis of the determination of cell survival or death strategy [7, 59, 109].

Oxygen consumption and regulation of the electron transport chain. At low physiological concentrations (nanomolar), NO regulates the effectiveness of oxidative phosphorylation and affects matrix $\mathrm{pH}$ [7]. At normal oxygen partial pressure, NO reduces $\mathrm{O}_{2}$ absorption in mitochondria and inhibits mitochondrial respiration in various tissues. Nitric oxide reversibly binds to and suppresses the activity of electron transport chain complexes, complex IV is considered to be the most sensitive target $[9,112]$. Endogenously synthesized NO, reducing the activity of cytochrome $c$-oxidase, decreases the consumption 
of oxygen, which allows the optimal functioning of cell enzymes with low affinity to $\mathrm{O}_{2}[26,114]$. At the physiological level of $\mathrm{O}_{2}$, mitochondrial respiration in the state 3 is more sensitive to exogenous NO than in the state $4[7,114,117]$.

Respiratory chain complexes have different sensitivity to nitric oxide. A relatively prolonged action of $0.5-1 \mu \mathrm{M}$ of $\mathrm{NO}$ selectively and reversibly inhibits NADH dehydrogenase activity of mitochondrial complex I by S-nitrosylation of important thiol residues in intact cells and isolated organelles $[19,59,109]$. Nitric oxide at concentrations of 0.3$0.5 \mu \mathrm{M}$ inhibits the transport of electrons between cytochromes b and c1 in the respiratory chain complex III, possibly interacting with Fe-S centers [59, 119]. In experiments on mitochondria of cardiomyocytes, skeletal muscle, liver, synaptosomes, it has been shown that NO reversibly binds to cytochrome c-oxidase already at 10-20 nM concentrations of NO in the matrix; nitric oxide nitrosylates the iron of heme subunit a-a3, also interacts with the coppercontaining center, which leads to the inhibition of electron transfer to $\mathrm{O}_{2}$. Semi-maximal inhibition of cytochrome $c$-oxidase occurs at 50-100 nM of NO $[19,59]$. When cytochrome $c$-oxidase is inhibited, the level of reduced components of the electron transport chain, in particular, ubisemiquinone, increases. Complex II, considering the content of iron-sulfur centers, can also be a potential target of NO. All of the above processes can raise the rate of ' $\mathrm{O}_{2}{ }^{-}$and $\mathrm{H}_{2} \mathrm{O}_{2}$ production in mitochondria [19, 30, 59, 119]. At the same time, the result of NO-induced inhibition of the electron transport chain is the partial depolarization of the inner mitochondrial membrane, which may have a protective effect, reducing the intensity of oxygen active forms generation. In our studies on rat uterine smooth muscle cells through use the laser confocal microscopy method and the potential-sensitive probe of 3,3'-dihexyloxacarbocyanine, a decrease in the electrical potential of the inner membrane of mitochondria during the action of $0.1 \mathrm{mM}$ of sodium nitroprusside (widely used NO donor) by about $17 \%$ is demonstrated [120].

Changes in the intensity of oxidative phosphorylation under $\mathrm{NO}$ action are an important factor in $\mathrm{O}_{2}$ consumption regulation between cells in the walls of large vessels and in tissues at different distances from capillaries. The cells that are close to the bloodstream are more supplied with $\mathrm{L}$-arginine and $\mathrm{O}_{2}$, which in turn stimulate mtNOS and NO production. Nitric oxide limits the consumption of $\mathrm{O}_{2}$ by well- oxidized cells, forcing $\mathrm{O}_{2}$ to diffuse to more distant from the blood flow sites $[6,118]$.

Nitric oxide at high concentrations leads to a series of harmful effects in mitochondria: irreversible inhibition of the respiratory chain, increased production of oxygen active forms, mitochondrial membrane depolarization, cytochrome $c$ release into the cytosol (occurs either due to mitochondria membrane potential loss, or due to the nitrosylation of cytochrome $c$ tyrosine residue), nitrosylation of a number of mitochondrial proteins [6, 9, 21, 35, 59, 121]. The described pathological phenomena, which result in the collapse of mitochondrial energetics and the development of apoptosis, have been called mitochondrial dysfunction. The latter, according to modern ideas, can cause endothelial dysfunction, too $[82,122]$. The amplified generation of superoxide anion and peroxynitrite induces $\mathrm{BH}_{4}$ oxidation, which leads to the "uncoupling" of mtNOS: it transforms from the NO-generating to the superoxide-producing enzyme, resulting in a further disorder of electron transport chain normal functioning. Peroxynitrite nitrates tyrosine residues of its components and plays a key role in apoptosis [6, 9, 18, 109, 123].

Formation of ultra-high NO quantities in the cell, for example, under conditions of inflammation and iNOS expression increment, leads to competition between $\mathrm{NO}$ and $\mathrm{O}_{2}$ for mitochondria metal proteins, resulting in NO-dependent hypoxia (nitroxia). In mitochondria under these conditions high levels of active forms of nitrogen and oxygen are observed, which irreversibly inhibit the electron transport chain, block ATP synthesis, have cytotoxic effects $[5,6,21,109,123]$.

$\mathrm{Ca}^{2+}$ homeostasis in mitochondria as an $\mathrm{ob}$ ject of NO regulatory influence. The optimal work of $\mathrm{Ca}^{2+}$ transport systems of the inner mitochondrial membrane ensures both the actual cell $\mathrm{Ca}^{2+}$ homeostasis and the functional activity of $\mathrm{Ca}^{2+}$-dependent processes in mitochondria, such as the normal course of reactions of the electron transport chain and metabolic processes in the matrix. In vivo experiments, convincing evidence of nitrogen oxide ability to modulate $\mathrm{Ca}^{2+}$ transport processes in mitochondria of cardiomyocytes, smooth muscle cells of blood vessels and hepatocytes are given [9, 124]. We have found that a 15-minute pre-incubation of isolated rat uterine smooth muscle mitochondria with sodium nitroprusside (SNP) resulted in a significant increase in energy-dependent (in the presence of succinate and $\mathrm{MgATP}{ }^{2-}$ ) accumulation of $\mathrm{Ca}^{2+}$ by organelles (Fig. 6) [125]. 
Similar results were obtained by other authors while studying short-term effects of nitroglycerin in vivo in the aorta, myocardium and rat liver [124]. In the cited work, at the same time, the reduction of the organelle membrane potential by $28-30 \%$ was registered. Consequently, the growth of mitochondria capacity for $\mathrm{Ca}^{2+}$ in different tissues both in vivo and in vitro may be due to the activation of $\mathrm{Ca}^{2+}$-uniporter and may possibly depend little on changes in the membrane potential in a relatively narrow range.

In order to prove the role of the uniporter in the investigated process, we used the protonophore CCCP and the inhibitor of the electrophoretic pathway of $\mathrm{Ca}^{2+}$ accumulation by mitochondria - ruthenium red. It was found that $10 \mu \mathrm{M}$ of CCCP and ruthenium red effectively suppress $\mathrm{Ca}^{2+}$ accumulation by mitochondria in the presence of SNP (Fig. 6). Meanwhile, the inhibitor of PTP $-5 \mu \mathrm{M}$ of cyclosporin A almost did not affect the SNP activated energy-dependent $\mathrm{Ca}^{2+}$ accumulation by mitochondria (Fig. 6). The results obtained indicate the insignificant role of the cyclosporin-sensitive pore in biochemical mechanisms of $\mathrm{Ca}^{2+}$ transport stimu-

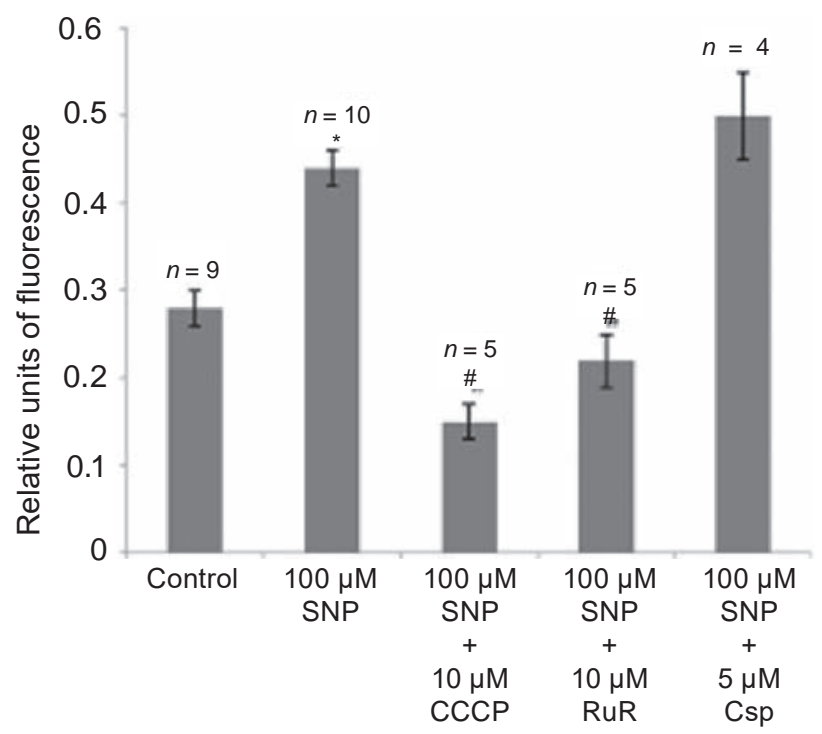

Fig. 6. Influence of modifiers of transmembrane $\mathrm{Ca}^{2+}$ exchange in myometrium mitochondria on energydependent cation transport under conditions of SNP activating effect; $C C C P$ - carbonyl cyanide 3-chlorophenyl hydrazone, RuR - ruthenium red, Csp cyclosporine, *hanges are significant in relation to the control, \# in relation to the action of $100 \mu \mathrm{M}$ of SNP, $P \leq 0.05$. Changes in $\mathrm{Ca}^{2+}$ concentration in the mitochondrial matrix were measured using the $\mathrm{Ca}^{2+}$-sensitive fluorescence probe Fluo-4 AM lation in mitochondria under the influence of NO. At the same time, in experiments performed on rat aorta and myocardium in conditions of nitroglycerin injection to animals, it was shown that the increase of mitochondria $\mathrm{Ca}^{2+}$-capacity is precisely due to the inhibition of the PTP by nitric oxide [126, 127]. The same authors in experiments on isolated mitochondria, unlike the experiments in vivo, demonstrated the decrease in $\mathrm{Ca}^{2+}$-capacity of the organelles during the action of NO donor, what is explained by the activation of the cation release through the $\mathrm{Ca}^{2+}$ uniporter caused by the depolarization of mitochondria. The difference between the results obtained in our studies and those described in the cited works may be related to the tissue specificity of the effect and the difference in the chemical structures of the used NO donors.

Mitochondria of individual cell parts are affected by different $\mathrm{Ca}^{2+}$ concentrations. Those located near the endoplasmic reticulum microdomains containing IP3-activated or ryanodine-sensitive $\mathrm{Ca}^{2+}$ channels are in high (tens of $\mu \mathrm{M}$ ) concentrations of $\mathrm{Ca}^{2+}$. They are able to efficiently accumulate this cation if necessary, in particular, during the massive release of $\mathrm{Ca}^{2+}$ from the sarcoplasmic reticulum of muscle cells while excitation. The isoform I of the ryanodine receptor is colocalized with the inner mitochondrial membrane, which may be one of the reticular and mitochondrial $\mathrm{Ca}^{2+}$-pool integration mechanisms [9, 26, 128]. According to the abovedescribed results, a nitric oxide of mitochondrial and exogenous origin is able to modulate these transport processes, changing $\mathrm{Ca}^{2+}$ accumulation efficiency by mitochondria.

Ions of Ca can regulate the functioning of mitochondria by activating key metabolic enzymes: pyruvate dehydrogenase, NAD-dependent isocitrate and 2-oxoglutarate dehydrogenases, $\alpha$-ketoglutarate dehydrogenase [27], and of course mtNOS [21, 26, 129]. Strengthening of $\mathrm{Ca}^{2+}$-dependent dehydrogenase functioning leads to an increase in oxygen consumption, while stimulation of mtNOS activity leads to the opposite effect. [28, 69, 129]. Activation of dehydrogenases and mtNOS is achieved at various concentrations of $\mathrm{Ca}^{2+}$ : for the first, it is lower than $0.2 \mu \mathrm{M}$, for the latter it is $1 \mu \mathrm{M}[26,27]$. Thus, Ca ions positively regulate the activity of $\mathrm{Ca}^{2+}$ dependent Krebs cycle dehydrogenases, which supply NADH to the respiratory chain, and the activity of mtNOS, which in turn, reciprocally affects oxygen consumption and the intensity of oxidative phosphorylation in mitochondria [5, 28, 109]. 
$\mathrm{NO}, \mathrm{Ca}^{2+}$ and mitochondrial movement. Mitochondria have greater mobility at the cytosolic $\mathrm{Ca}^{2+}$ concentration of $100 \mathrm{nM}$ or less in the cell resting state. As the level of $\mathrm{Ca}^{2+}$ increases, the intensity of the movement decreases. A rise in the cation content in the cytoplasm up to $0.4 \mu \mathrm{M}$, which corresponds to the concentration of free intramitochondrial $\mathrm{Ca}^{2+}$ of about $1.2 \mu \mathrm{M}$, results in a halving of organelle mobility [26, 130]. Under these conditions, mitochondria $\mathrm{Ca}^{2+}$-dependent dehydrogenases are almost completely activated (for example, the activation constant for $\mathrm{Ca}^{2+}$ of $\alpha$-ketoglutarate dehydrogenase is $0.2 \mu \mathrm{M}$ ), while the mtNOS activity is approximately of the halved maximum value $\left(K_{0.5}\right.$ for $\left.\mathrm{Ca}^{2+}-1 \mu \mathrm{M}\right)$. Against this background, NO, formed by mtNOS, inhibits mitochondrial respiration by $27 \%$ through inhibiting the cytochrome $c$-oxidase, also resulting in a rate decrease of oxidative phosphorylation. Further growth of $\mathrm{Ca}^{2+}$ concentration to $1 \mu \mathrm{M}$ in the cytosol is accompanied by suppression of the organelle mobility by $70 \%$ (the content of free $\mathrm{Ca}^{2+}$ in the matrix is $2.3 \mu \mathrm{M}$ ). Under these conditions, the activity of dehydrogenase is maximal, and the activity of mtNOS is $70 \%$, which leads to the reduction in oxygen absorption by 35\% [26]. Consequently, $\mathrm{Ca}^{2+}$ induced inhibition of mitochondrial mobility occurs on the background of enhanced cation accumulation by the matrix, activation of bioenergetic processes and stimulation of endogenous NO generation, and subsequently is accompanied by a decrease in oxygen consumption and intensity of oxidative phosphorylation.

PTP, NO and apoptosis. It has been shown that NO can either prevent or facilitate the opening of PTP [5]. It depends simultaneously on the concentration of $\mathrm{NO}$ and the intensity of ${ }^{\circ} \mathrm{O}_{2}{ }^{-}$generation in mitochondria. At the physiological level of NO, the opening of the pore is inhibited with a half-inhibition constant of about $10 \mathrm{nM}$ [9]. High concentrations of NO sensibilisate the PTP, making it more sensitive to such factors of opening as the increased $\mathrm{Ca}^{2+}$ concentration in the matrix, low level of ATP and the enhancement of ${ }^{\circ} \mathrm{O}_{2}{ }^{-}$production. The opening of the pore causes rapid depolarization, exhaustion of the ATP pool, apoptotic, and in some cases, necrotic death of the cell. With this in mind, mtNOS plays an important role in regulating of PTP activity [7, 9, 36, 68].

It is presumed that absorption of $\mathrm{Ca}^{2+}$ by respiring mitochondria and mtNOS stimulation may increase the formation of $\mathrm{ONOO}^{-}$which, in turn, ini- tiates the release of $\mathrm{Ca}^{2+}$ from the matrix with subsequent mtNOS activity fall [7, 69, 131]. Consequently, $\mathrm{mtNOS}$-mediated peroxynitrite formation provides the release of $\mathrm{Ca}^{2+}$ and cytochrome $c$ from mitochondria, resulting in the development of Bcl-2 - dependent apoptosis [5, 35, 59, 132]. The release of cytochrome $c$ under these conditions does not depend on PTP opening [6].

Therefore, depending on the concentration and chemical microenvironment, NO has both anti- and proapoptotic effects that are realized at mitochondria level.

Conclusions and perspectives. Nitric oxide is an almost universal secondary messenger and regulator of numerous cellular processes, which result in the hyperfine regulation of its synthesis (functioning isoforms of NO-synthase) at the level of transcription, translation, posttranslational covalent modifications, protein-protein and protein-lipid interactions, and by changing the availability of cofactors and substrate. Limited diffusion of nitric oxide precisely defined localization and specific regulation of NO synthase isoforms (eNOS, nNOS, mtNOS) in a cell that allows NO to perform specific functions in separate cytosolic microdomains. As a paracrine regulator, nitric oxide may have certain vectoriality in its tissue effects, which in the case of the vascular wall is due to the existence of myoendothelial gap junction.

One of the nNOS splice variants, namely, the constitutive mtNOS, determines the possibility of endogenous biosynthesis of nitric oxide in energized mitochondria in the presence of $\mathrm{O}_{2}$. The PDZ domain provides the interaction of this enzyme with complexes I or/and IV of the respiratory chain. Endogenous NO formation by mitochondria depends on their metabolic state, electrical potential on the inner mitochondrial membrane and is a $\mathrm{Ca}^{2+}$-dependent process.

Nitric oxide at physiological concentrations is a regulator of mitochondrial bioenergetics, reversibly inhibiting the activity of the electron transport chain, respiration and oxidative phosphorylation. Partial depolarization of the inner mitochondrial membrane and inhibition of PTP can be considered as nitric oxide protective effect on mitochondria, aimed at reducing the rate of generation of oxygen active forms and the development of apoptosis.

Nitric oxide provides fine regulatory relation between mtNOS activity and intramitochondrial $\mathrm{Ca}^{2+}, \mathrm{pH}$, L-arginine, $\mathrm{O}_{2}$ and mitochondria redox state. 
Considering the key role of mitochondria in cell bioenergetics and in determining its fate (life or death), important directions for future investigations may be the search for specific modulators (activators/inhibitors) of mtNOS activity, regulation of its expression and the mechanism of traffic to mitochondria, the final determination of submitochondrial enzyme localization, the establishment of the relationship between the electronic transport chain and mtNOS functioning, etc. The questions of endogenously synthesized NO influence on other cellular compartments, in particular on the endoplasmic reticulum localized around the mitochondria, and the contribution of such cellular sources of $\mathrm{NO}$ as plasmalemma and reticulum to the regulation of the actual mitochondrial processes remain unexplained.

\section{БІОСИНТЕЗ ОКСИДУ АЗОТУ 3 L-АРГІНІНУ. ОСОБЛИВОСТІ УТВОРЕННЯ ТА ФУНКЦІОНАЛЬНА РОЛЬ NO В МІТОХОНДРІЯХ}

\section{Г. В. Данилович, Т. В. Богач, Ю. В. Данилович}

Інститут біохімії ім. О. В. Палладіна НАН України, Київ; e-mail: danylovych@biochem.kiev.ua

В огляді проаналізовано сучасні дані щодо біохімічних закономірностей біосинтезу оксиду азоту із L-аргініну в клітинах ссавців за нормоксичних умов. Розглянуто структуру та особливості регуляції ізоформ NO-синтази. Акценти зроблено на новітніх уявленнях про компартменталізацію в клітинах окремих ізоформ цього ензиму та можливості спрямованого транспорту оксиду азоту в судинній стінці. Центральне місце в огляді приділено питанням ендогенного утворення NO в мітохондріях та його вірогідному фізіологічному значенню. Подано і власні результати по ідентифікації оксиду азоту в мітохондріях гладенького м'яза матки, біохімічні характеристики цього процесу, обговорено можливу роль NO в регуляції транспорту $\mathrm{Ca}^{2+}$ в мітохондріях.

Ключові слова: оксид азоту, мітохондрії, NO-синтаза, клітинні компартменти, кальцій, гладенькі м'язи.

\section{БИОСИНТЕЗ ОКСИДА АЗОТА ИЗ L-АРГИНИНА. ОСОБЕННОСТИ ОБРАЗОВАНИЯ И ФУНКЦИОНАЛЬНАЯ РОЛЬ NО В МИТОХОНДРИЯХ}

\author{
А. В. Данилович, Т. В. Богач, \\ Ю. В. Данилович
}

\author{
Институт биохимии им. А. В. Палладина \\ НАН Украины, Киев; \\ e-mail: danylovych@biochem.kiev.ua
}

В обзоре дан анализ современных данных относительно биохимических закономерностей биосинтеза оксида азота из L-аргинина в клетках млекопитающих в условиях нормоксии. Рассмотрена структура и особенности регуляции изоформ NO-синтазы. Сделаны акценты на новейших представлениях о компартментализации в клетках отдельных изоформ этого энзима и возможности направленного транспорта оксида азота в стенке сосудов. Центральное место в обзоре посвящено вопросам эндогенного образования NO в митохондриях и его вероятному физиологическому значению. Представлены и собственные результаты по идентификации оксида азота в митохондриях гладкой мышцы матки, биохимические характеристики этого процесса, обсуждена возможная роль $\mathrm{NO}$ в регуляции транспорта $\mathrm{Ca}^{2+}$ в митохондриях.

К лючовы е слова: оксид азота, митохондрии, NO-синтаза, клеточные компартменты, кальций, гладкие мышцы.

\section{References}

1. Sybirna NO, Lyuta MYa, Klymyshyn NI. Molecular mechanisms of nitric oxide deposition in erythrocytes. Studia Biologica. 2010; 4(1): 143-160. (In Ukrainian).

2. Treuer AV, Gonzalez DR. Nitric oxide synthases, S-nitrosylation and cardiovascular health: from molecular mechanisms to therapeutic opportunities (review). Mol Med Rep. 2015; 11(3): 1555-1565.

3. Alderton WK, Cooper CE, Knowles RG. Nitric oxide synthases: structure, function and inhibition. Biochem J. 2001; 357(Pt 3): 593-615. 
4. Förstermann U, Sessa WC. Nitric oxide synthases: regulation and function. Eur Heart $J$. 2012; 33(7): 829-837.

5. Levine AB, Punihaole D, Levine TB. Characterization of the role of nitric oxide and its clinical applications. Cardiology. 2012; 122(1): 55-68.

6. Haynes V, Elfering SL, Squires RJ, Traaseth N, Solien J, Ettl A, Giulivi C. Mitochondrial nitricoxide synthase: role in pathophysiology. IUBMB Life. 2003; 55(10-11): 599-603.

7. Zaobornyj T, Ghafourifar P. Strategic localization of heart mitochondrial NOS: a review of the evidence. Am J Physiol Heart Circ Physiol. 2012; 303(11): H1283-H1293.

8. Buxton IL. Regulation of uterine function: a biochemical conundrum in the regulation of smooth muscle relaxation. Mol Pharmacol. 2004; 65(5): 1051-1059.

9. Davidson SM, Duchen MR. Effects of NO on mitochondrial function in cardiomyocytes: Pathophysiological relevance. Cardiovasc Res. 2006; 71(1): 10-21.

10. Durán WN, Breslin JW, Sánchez FA. The NO cascade, eNOS location, and microvascular permeability. Cardiovasc Res. 2010; 87(2): 254261.

11. Kleschyov AL. The NO-heme signaling hypothesis. Free Radic Biol Med. 2017; 112: 544-552.

12. Leite AC, Oliveira HC, Utino FL, Garcia R, Alberici LC, Fernandes MP, Castilho RF, Vercesi AE. Mitochondria generated nitric oxide protects against permeability transition via formation of membrane protein S-nitrosothiols. Biochim Biophys Acta. 2010; 1797(6-7): 12101216.

13. Ghimire K, Altmann HM, Straub AC, Isenberg JS. Nitric oxide: what's new to NO? Am J Physiol Cell Physiol. 2017; 312(3): C254-C262.

14. Corbin JD. Mechanisms of action of PDE5 inhibition in erectile dysfunction. Int J Impot Res. 2004; 16(Suppl 1): S4-S7.

15. Mutchler SM, Straub AC. Compartmentalized nitric oxide signaling in the resistance vasculature. Nitric Oxide. 2015; 49: 8-15.

16. Kovalyov IV, Baskakov MB, Kapilevich LV, Medvedev MA. Role of nitric oxide in the regulation of electrical and contractive activity of unstriped muscles. Bull Sibir Med. 2004; 1: 7-26. (In Russian).
17. Zhao Y, Vanhoutte PM, Leung SW. Vascular nitric oxide: Beyond eNOS. J Pharmacol Sci. 2015; 129(2): 83-94.

18. Litvinova L, Atochin DN, Fattakhov N, Vasilenko M, Zatolokin P, Kirienkova E. Nitric oxide and mitochondria in metabolic syndrome. Front Physiol. 2015; 6: 20.

19. Franco MC, Antico Arciuch VG, Peralta JG, Galli S, Levisman D, López LM, Romorini L, Poderoso JJ, Carreras MC. Hypothyroid phenotype is contributed by mitochondrial complex I inactivation due to translocated neuronal nitric-oxide synthase. $J$ Biol Chem. 2006; 281(8): 4779-4786.

20. Nosarev AV, Smagliy LV, Anfinogenova Y, Popov SV, Kapilevich LV. Exercise and NO production: relevance and implications in the cardiopulmonary system. Front Cell Dev Biol. 2015; 2: 73.

21. Giulivi C. Mitochondria as generators and targets of nitric oxide. Novartis Found Symp. 2007; 287: 92-104.

22. Boveris A. Mitochondrial production of superoxide radical and hydrogen peroxide, in: M. Reivich, R. Coburn, S. Lahiri, B. Chance (Eds.), Tissue hypoxia and ischemia. Plenun Publishing corporation, New York, 1977. P. 6782.

23. Korshunov SS, Skulachev VP, Starkov AA. High protonic potential actuates a mechanism of production of reactive oxygen species in mitochondria. FEBS Lett. 1997; 416(1): 15-18.

24. Piantadosi CA, Suliman HB. Redox regulation of mitochondrial biogenesis. Free Radic Biol Med. 2012; 53(11): 2043-2053.

25. Brown GC, Borutaite V. Nitric oxide and mitochondrial respiration in the heart. Cardiovasc Res. 2007; 75(2): 283-290.

26. Giulivi C, Kato K, Cooper CE. Nitric oxide regulation of mitochondrial oxygen consumption I: cellular physiology. Am J Physiol Cell Physiol. 2006; 291(6): C1225-C1231.

27. Gellerich FN, Gizatullina Z, Trumbeckaite S, Nguyen HP, Pallas T, Arandarcikaite O, Vielhaber S, Seppet E, Striggow F. The regulation of OXPHOS by extramitochondrial calcium. Biochim Biophys Acta. 2010; 1797(6-7): 1018-1027.

28. Traaseth N, Elfering S, Solien J, Haynes V, Giulivi C. Role of calcium signaling in the activation of mitochondrial nitric oxide synthase 
and citric acid cycle. Biochim Biophys Acta. 2004; 1658(1-2): 64-71.

29. Nisoli E, Carruba MO. Nitric oxide and mitochondrial biogenesis. J Cell Sci. 2006; 119(Pt 14): 2855-2862.

30. Tengan CH, Rodrigues GS, Godinho RO. Nitric oxide in skeletal muscle: role on mitochondrial biogenesis and function. Int J Mol Sci. 2012; 13(12): 17160-17184.

31. Salem MM, Shalbaf M, Gibbons NC, Chavan B, Thornton JM, Schallreuter KU. Enhanced DNA binding capacity on up-regulated epidermal wild-type p53 in vitiligo by $\mathrm{H}_{2} \mathrm{O}_{2}$-mediated oxidation: a possible repair mechanism for DNA damage. FASEB J. 2009; 23(11): 3790-3807.

32. Demicheli V, Moreno DM, Jara GE, Lima A, Carballal S, Ríos N, Batthyany C, FerrerSueta G, Quijano C, Estrín DA, Martí MA, Radi R. Mechanism of the reaction of human manganese superoxide dismutase with peroxynitrite: nitration of critical Tyrosine 34 . Biochemistry. 2016; 55(24): 3403-3417.

33. Tórtora V, Quijano C, Freeman B, Radi R, Castro L. Mitochondrial aconitase reaction with nitric oxide, S-nitrosoglutathione, and peroxynitrite: mechanisms and relative contributions to aconitase inactivation. Free Radic Biol Med. 2007; 42(7): 1075-1088.

34. Gong L, Liu FQ, Wang J, Wang XP, Hou XG, Sun Y, Qin WD, Wei SJ, Zhang Y, Chen L, Zhang MX. Hyperglycemia induces apoptosis of pancreatic islet endothelial cells via reactive nitrogen species-mediated Jun N-terminal kinase activation. Biochim Biophys Acta. 2011; 1813(6): 1211-1219.

35. Santos C, Anilkumar N, Zhang M, Brewer AC, Shah AM. Redox signaling in cardiac myocytes. Free Radic Biol Med. 2011; 50(7): 777-793.

36. Brown GC. Nitric oxide and neuronal death. Nitric Oxide. 2010; 23(3): 153-165.

37. Radi R, Cassina A, Hodara R. Nitric oxide and peroxynitrite interactions with mitochondria. Biol Chem. 2002; 383(3-4): 401-409.

38. Andrew PJ, Mayer B. Enzymatic function of nitric oxide synthases. Cardiovasc Res. 1999; 43(3): 521-531.

39. Kone BC, Kuncewicz T, Zhang W, Yu ZY. Protein interactions with nitric oxide synthases: controlling the right time, the right place, and the right amount of nitric oxide. Am J Physiol Renal Physiol. 2003; 285(2): F178-F190.
40. Daff S. NO synthase: structures and mechanisms. Nitric Oxide. 2010; 23(1): 1-11.

41. Daff S, Sagami I, Shimizu T. The 42-amino acid insert in the FMN domain of neuronal nitric-oxide synthase exerts control over $\mathrm{Ca}(2+) /$ calmodulin-dependent electron transfer. $J$ Biol Chem. 1999; 274(43): 30589-30595.

42. Elfering SL, Sarkela TM, Giulivi C. Biochemistry of mitochondrial nitric-oxide synthase. J Biol Chem. 2002; 277(41): 38079-38086.

43. Förstermann U, Closs EI, Pollock JS, Nakane M, Schwarz P, Gath I, Kleinert H. Nitric oxide synthase isozymes. Characterization, purification, molecular cloning, and functions. Hypertension. 1994; 23(6 Pt 2): 1121-1131.

44. Ogura T, Yokoyama T, Fujisawa H, Kurashima Y, Esumi $\mathrm{H}$. Structural diversity of neuronal nitric oxide synthase mRNA in the nervous system. Biochem Biophys Res Commun. 1993; 193(3): 1014-1022.

45. Silvagno F, Xia H, Bredt DS. Neuronal nitricoxide synthase-mu, an alternatively spliced isoform expressed in differentiated skeletal muscle. J Biol Chem. 1996; 271(19): 1120411208.

46. Brenman JE, Xia H, Chao DS, Black SM, Bredt DS. Regulation of neuronal nitric oxide synthase through alternative transcripts. Dev Neurosci. 1997; 19(3): 224-231.

47. De Palma C, Morisi F, Pambianco S, Assi E, Touvier T, Russo S, Perrotta C, Romanello V, Carnio S, Cappello V, Pellegrino P, Moscheni C, Bassi MT, Sandri M, Cervia D, Clementi E. Deficient nitric oxide signalling impairs skeletal muscle growth and performance: involvement of mitochondrial dysregulation. Skelet Muscle. 2014; 4(1): 22.

48. Christopherson KS, Hillier BJ, Lim WA, Bredt DS. PSD-95 assembles a ternary complex with the N-methyl-D-aspartic acid receptor and a bivalent neuronal NO synthase PDZ domain. J Biol Chem. 1999; 274(39): 27467-27473.

49. Brenman JE, Chao DS, Gee SH, McGee AW, Craven SE, Santillano DR, Wu Z, Huang F, Xia H, Peters MF, Froehner SC, Bredt DS. Interaction of nitric oxide synthase with the postsynaptic density protein PSD-95 and alpha1syntrophin mediated by PDZ domains. Cell. 1996; 84(5): 757-767.

50. Rodríguez-Crespo I, Straub W, Gavilanes F, Ortiz de Montellano PR. Binding of dynein light chain (PIN) to neuronal nitric oxide synthase 
in the absence of inhibition. Arch Biochem Biophys. 1998; 359(2): 297-304.

51. Hemmens B, Woschitz S, Pitters E, Klösch B, Völker C, Schmidt K, Mayer B. The protein inhibitor of neuronal nitric oxide synthase (PIN): characterization of its action on pure nitric oxide synthases. FEBS Lett. 1998; 430(3): 397-400.

52. King SM, Barbarese E, Dillman JF 3rd, Patel-King RS, Carson JH, Pfister KK. Brain cytoplasmic and flagellar outer arm dyneins share a highly conserved Mr 8,000 light chain. J Biol Chem. 1996; 271(32): 19358-19366.

53. Heinonen I, Saltin B, Hellsten Y, Kalliokoski KK. The effect of nitric oxide synthase inhibition with and without inhibition of prostaglandins on blood flow in different human skeletal muscles. Eur J Appl Physiol. 2017; 117(6): 1175-1180.

54. Li Q, Chen Y, Zhang X, Zuo S, Ge H, Chen Y, Liu X, Zhang JH, Ruan H, Feng H. Scutellarin attenuates vasospasm through the Erk5-KLF2eNOS pathway after subarachnoid hemorrhage in rats. J Clin Neurosci. 2016; 34: 264-270.

55. Tsai TN, Lin WS, Wu CH, Lin WY, Chu KM, Cheng CC, Hsu CH, Tsai WC, Cheng SM, Yang SP. Activation of Krüppel-Like Factor 2 with Ginkgo Biloba Extract Induces eNOS Expression and Increases NO Production in Cultured Human Umbilical Endothelial Cells. Acta Cardiol Sin. 2014; 30(3): 215-222.

56. Varejckova M, Gallardo-Vara E, Vicen M, Vitverova B, Fikrova P, Dolezelova E, Rathouska J, Prasnicka A, Blazickova K, Micuda S, Bernabeu C, Nemeckova I, Nachtigal P. Soluble endoglin modulates the pro-inflammatory mediators NF- $\kappa$ B and IL-6 in cultured human endothelial cells. Life Sci. 2017; 175: 52-60.

57. Lee JE, Yuan H, Liang FX, Sehgal PB. Nitric oxide scavenging causes remodeling of the endoplasmic reticulum, Golgi apparatus and mitochondria in pulmonary arterial endothelial cells. Nitric Oxide. 2013; 33: 64-73.

58. Feron O, Belhassen L, Kobzik L, Smith TW, Kelly RA, Michel T. Endothelial nitric oxide synthase targeting to caveolae. Specific interactions with caveolin isoforms in cardiac myocytes and endothelial cells. J Biol Chem. 1996; 271(37): 22810-22814.

59. Carreras MC, Poderoso JJ. Mitochondrial nitric oxide in the signaling of cell integrated responses. Am J Physiol Cell Physiol. 2007; 292(5): C1569-C1580.
60. Shaul PW, Smart EJ, Robinson LJ, German Z, Yuhanna IS, Ying Y, Anderson RG, Michel T. Acylation targets emdothelial nitric-oxide synthase to plasmalemmal caveolae. $\mathrm{J}$ Biol Chem. 1996; 271(11): 6518-6522.

61. Michel T. Targeting and translocation of endothelial nitric oxide synthase. Braz J Med Biol Res. 1999; 32(11): 1361-1366.

62. Dimmeler S, Fleming I, Fisslthaler B, Hermann C, Busse R, Zeiher AM.Activation of nitric oxide synthase in endothelial cells by Akt-dependent phosphorylation. Nature. 1999; 399(6736): 601-605.

63. Komeima K, Hayashi Y, Naito Y, Watanabe Y. Inhibition of neuronal nitric-oxide synthase by calcium/ calmodulin-dependent protein kinase IIalpha through Ser847 phosphorylation in NG108-15 neuronal cells. J Biol Chem. 2000; 275(36): 28139-28143.

64. Shashar M, Chernichovski T, Pasvolsky O, Levi S, Grupper A, Hershkovitz R, Weinstein T, Schwartz IF. Vascular Endothelial Growth Factor Augments Arginine Transport and Nitric Oxide Generation via a KDR Receptor Signaling Pathway. Kidney Blood Press Res. 2017; 42(2): 201-208.

65. Wu G, Morris SM. Arginine metabolism: nitric oxide and beyond. Biochem J. 1998; 336(Pt 1): $1-17$.

66. Bauer EM, Qin Y, Miller TW, Bandle RW, Csanyi G, Pagano PJ, Bauer PM, Schnermann J, Roberts DD, Isenberg JS. Thrombospondin-1 supports blood pressure by limiting eNOS activation and endothelial-dependent vasorelaxation. Cardiovasc Res. 2010; 88(3): 471-481.

67. Rogers NM, Sharifi-Sanjani M, Csányi G, Pagano PJ, Isenberg JS. Thrombospondin-1 and CD47 regulation of cardiac, pulmonary and vascular responses in health and disease. Matrix Biol. 2014; 37: 92-101.

68. Dedkova EN, Blatter LA. Characteristics and function of cardiac mitochondrial nitric oxide synthase. J Physiol. 2009; 587(Pt 4): 851-872.

69. Sanchez-Padilla J, Guzman JN, Ilijic E, Kondapalli J, Galtieri DJ, Yang B, Schieber S, Oertel W, Wokosin D, Schumacker PT, Surmeier DJ. Mitochondrial oxidant stress in locus coeruleus is regulated by activity and nitric oxide synthase. Nat Neurosci. 2014; 17(6): 832-840.

70. Connelly L, Jacobs AT, Palacios-Callender M, Moncada S, Hobbs AJ. Macrophage endothelial 
nitric-oxide synthase autoregulates cellular activation and pro-inflammatory protein expression. J Biol Chem. 2003; 278(29): 2648026487.

71. van Straaten JF, Postma DS, Coers W, Noordhoek JA, Kauffman HF, Timens W. Macrophages in lung tissue from patients with pulmonary emphysema express both inducible and endothelial nitric oxide synthase. Mod Pathol. 1998; 11(7): 648-655.

72. Butcher JT, Johnson T, Beers J, Columbus L, Isakson BE. Hemoglobin $\alpha$ in the blood vessel wall. Free Radic Biol Med. 2014; 73: 136-142.

73. Lin X, Xu Q, Veenstra RD. Functional formation of heterotypic gap junction channels by connexins-40 and -43. Channels (Austin). 2014; 8(5): 433-443.

74. Pogoda K, Füller M, Pohl U, Kameritsch P. NO, via its target $\mathrm{Cx} 37$, modulates calcium signal propagation selectively at myoendothelial gap junctions. Cell Commun Signal. 2014; 12: 33.

75. Nishida CR, Ortiz de Montellano PR. Autoinhibition of endothelial nitric-oxide synthase. Identification of an electron transfer control element. J Biol Chem. 1999 May 21;274(21):14692-8.

76. Chreifi G, Li H, McInnes CR, Gibson CL, Suckling CJ, Poulos TL. Communication between the zinc and tetrahydrobiopterin binding sites in nitric oxide synthase. Biochemistry. 2014; 53(25): 4216-4223.

77. Schmidt TS, Alp NJ. Mechanisms for the role of tetrahydrobiopterin in endothelial function and vascular disease. Clin Sci (Lond). 2007; 113(2): 47-63.

78. Li H, Poulos TL. Structure-function studies on nitric oxide synthases. J Inorg Biochem. 2005; 99(1): 293-305.

79. Sheng JZ, Wang D, Braun AP. DAF-FM (4-amino5-methylamino-2',7'-difluorofluorescein) diacetate detects impairment of agonist-stimulated nitric oxide synthesis by elevated glucose in human vascular endothelial cells: reversal by vitamin C and L-sepiapterin. J Pharmacol Exp Ther. 2005; 315(2): 931-940.

80. Chuaiphichai S, McNeill E, Douglas G, Crabtree MJ, Bendall JK, Hale AB, Alp NJ, Channon KM. Cell-autonomous role of endothelial GTP cyclohydrolase 1 and tetrahydrobiopterin in blood pressure regulation. Hypertension. 2014; 64(3): 530-540.
81. Crabtree MJ, Tatham AL, Al-Wakeel Y, Warrick N, Hale AB, Cai S, Channon KM, Alp NJ. Quantitative regulation of intracellular endothelial nitric-oxide synthase (eNOS) coupling by both tetrahydrobiopterin-eNOS stoichiometry and biopterin redox status: insights from cells with tet-regulated GTP cyclohydrolase I expression. J Biol Chem. 2009; 284(2): 1136-1144.

82. Talib J, Kwan J, Suryo Rahmanto A, Witting PK, Davies MJ. The smoking-associated oxidant hypothiocyanous acid induces endothelial nitric oxide synthase dysfunction. Biochem J. 2014; 457(1): 89-97.

83. Simon A, Plies L, Habermeier A, Martiné U, Reining M, Closs EI. Role of neutral amino acid transport and protein breakdown for substrate supply of nitric oxide synthase in human endothelial cells. Circ Res. 2003; 93(9): 813-820.

84. Santhanam L, Christianson DW, Nyhan D, Berkowitz DE. Arginase and vascular aging. J Appl Physiol. 2008; 105(5): 1632-1642.

85. Durante W, Johnson FK, Johnson RA. Arginase: a critical regulator of nitric oxide synthesis and vascular function. Clin Exp Pharmacol Physiol. 2007; 34(9): 906-911.

86. Morris SM. Recent advances in arginine metabolism: roles and regulation of the arginases. Br J Pharmacol. 2009; 157(6): 922-930.

87. Elms S, Chen F, Wang Y, Qian J, Askari B, Yu Y, Pandey D, Iddings J, Caldwell RB, Fulton DJ. Insights into the arginine paradox: evidence against the importance of subcellular location of arginase and eNOS. Am J Physiol Heart Circ Physiol. 2013; 305(5): H651-H666.

88. Ferents IV, Brodyak IV, Lyuta MYa, Burda VA, Fedorovych AM, Sybirna NO. The effect of agmatine on L-arginine metabolism in erythrocytes under streptozotocin-induced diabetes in rats. Ukr Biokhim Zhurn. 2012; 84(3): 55-62. (In Ukrainian).

89. Closs EI, Scheld JS, Sharafi M, Förstermann U. Substrate supply for nitric-oxide synthase in macrophages and endothelial cells: role of cationic amino acid transporters. Mol Pharmacol. 2000; 57(1): 68-74.

90. Pollock JS, Förstermann U, Mitchell JA, Warner TD, Schmidt HH, Nakane M, Murad F. Purification and characterization of particulate endothelium-derived relaxing factor synthase from cultured and native bovine aortic 
endothelial cells. Proc Natl Acad Sci USA. 1991; 88(23): 10480-10484.

91. Ash DE. Structure and function of arginases. J Nutr. 2004; 134(10 Suppl): 2760S-2767S.

92. Porcelli V, Fiermonte G, Longo A, Palmieri F. The human gene SLC25A29, of solute carrier family 25, encodes a mitochondrial transporter of basic amino acids. J Biol Chem. 2014; 289(19): 13374-13384.

93. Boucher JL, Moali C, Tenu JP. Nitric oxide biosynthesis, nitric oxide synthase inhibitors and arginase competition for L-arginine utilization. Cell Mol Life Sci. 1999; 55(8-9): 1015-1028.

94. Que LG, George SE, Gotoh T, Mori M, Huang YC. Effects of arginase isoforms on NO Production by nNOS. Nitric Oxide. 2002; 6(1): 1-8.

95. Peng $\mathrm{H}$, Chen $\mathrm{L}$, Huang $\mathrm{X}$, Yang $\mathrm{T}$, Yu Z, Cheng G, Zhang G, Shi R. Vascular peroxidase 1 up regulation by angiotensin II attenuates nitric oxide production through increasing asymmetrical dimethylarginine in HUVECs. J Am Soc Hypertens. 2016; 10(9): 741-751.e3.

96. Cosentino F, Sill JC, Katusić ZS. Role of superoxide anions in the mediation of endothelium-dependent contractions. Hypertension. 1994; 23(2): 229-235.

97. Gorren AC, Mayer B. The versatile and complex enzymology of nitric oxide synthase. Biochemistry (Mosc). 1998 Jul;63(7):734-43.

98. Ghafourifar P, Richter C. Nitric oxide synthase activity in mitochondria. FEBS Lett. 1997; 418(3): 291-296.

99. Giulivi C, Poderoso JJ, Boveris A. Production of nitric oxide by mitochondria. J Biol Chem. 1998; 273(18): 11038-11043.

100. Haynes V, Elfering S, Traaseth N, Giulivi C. Mitochondrial nitric-oxide synthase: enzyme expression, characterization, and regulation. J Bioenerg Biomembr. 2004; 36(4): 341-346.

101. Valdez LB, Zaobornyj T, Boveris A. Mitochondrial metabolic states and membrane potential modulate mtNOS activity. Biochim Biophys Acta. 2006; 1757(3): 166-172.

102. Giulivi C. Functional implications of nitric oxide produced by mitochondria in mitochondrial metabolism. Biochem J. 1998; 332(Pt 3): 673679.

103. Dolińska M, Albrecht J. L-arginine uptake in rat cerebral mitochondria. Neurochem Int. 1998; 33(3): 233-236.
104. Danylovych YuV, Karakhim SA, Kolomiets OV, Danylovych GV, Kosterin SO. Identification of nitric oxide in mitochondria of myometrium cell. Biopolym Cell. 2015; 31(3): 174-178.

105. Tatoyan A, Giulivi C. Purification and characterization of a nitric-oxide synthase from rat liver mitochondria. J Biol Chem. 1998; 273(18): 11044-11048.

106. Boveris A, Valdez LB, Alvarez S, Zaobornyj T, Boveris AD, Navarro A. Kidney mitochondrial nitric oxide synthase. Antioxid Redox Signal. 2003; 5(3): 265-271.

107. Alvarez S, Boveris A. Mitochondrial nitric oxide metabolism in rat muscle during endotoxemia. Free Radic Biol Med. 2004;37(9): 1472-1478.

108. Bustamante J, Bersier G, Badin RA, Cymeryng C, Parodi A, Boveris A. Sequential NO production by mitochondria and endoplasmic reticulum during induced apoptosis. Nitric Oxide. 2002; 6(3): 333-341.

109. Ghafourifar P, Cadenas E. Mitochondrial nitric oxide synthase. Trends Pharmacol Sci. 2005; 26(4): 190-195.

110. Persichini T, Mazzone V, Polticelli F, Moreno S, Venturini G, Clementi E, Colasanti M. Mitochondrial type I nitric oxide synthase physically interacts with cytochrome c oxidase. Neurosci Lett. 2005; 384(3): 254-259.

111. Parihar MS, Nazarewicz RR, Kincaid E, Bringold U, Ghafourifar P. Association of mitochondrial nitric oxide synthase activity with respiratory chain complex I. Biochem Biophys Res Commun. 2008; 366(1): 23-28.

112. Gutierrez J, Ballinger SW, Darley-Usmar VM, Landar A. Free radicals, mitochondria, and oxidized lipids: the emerging role in signal transduction in vascular cells. Circ Res. 2006; 99(9): 924-932.

113. Chance B, Williams GR. Respiratory enzymes in oxidative phosphorylation. III. The steady state. J Biol Chem. 1955; 217(1): 409-427.

114. Valdez LB, Zaobornyj T, Boveris A. Functional activity of mitochondrial nitric oxide synthase. Methods Enzymol. 2005; 396: 444-455.

115. Danylovych G, Bohach T, Kolomiets O, Danylovych Yu. Biosynthesis and possible physiological role of nitric oxide in smooth muscle mitochondria. Current problems of biochemistry and cell biology: the $4^{\text {th }}$ international scientific conference materials, 5-6 October 2017, Dnipro, Ukraine/ ad. Ushakova GA. Dnipro: Lira, 2017. 
116. Bernardi P. Modulation of the mitochondrial cyclosporin A-sensitive permeability transition pore by the proton electrochemical gradient. Evidence that the pore can be opened by membrane depolarization. J Biol Chem. 1992; 267(13): 8834-8839.

117. Brookes PS, Kraus DW, Shiva S, Doeller JE, Barone MC, Patel RP, Lancaster JR Jr, DarleyUsmar V. Control of mitochondrial respiration by NO*, effects of low oxygen and respiratory state. J Biol Chem. 2003; 278(34): 31603-31609.

118. Nagendran J, Michelakis ED. Mitochondrial NOS is upregulated in the hypoxic heart: implications for the function of the hypertrophied right ventricle. Am J Physiol Heart Circ Physiol. 2009; 296(6): H1723-H1726.

119. Poderoso JJ, Carreras MC, Schöpfer F, Lisdero CL, Riobó NA, Giulivi C, Boveris AD, Boveris A, Cadenas E. The reaction of nitric oxide with ubiquinol: kinetic properties and biological significance. Free Radic Biol Med. 1999; 26(7-8): 925-935.

120. Danylovych YuV, Danylovych HV, Kolomiets OV, Kosterin SO, Karakhim SO, Chunikhin AYu. Investigation of nitrosactive compounds influence on polarization of the mitochondrial inner membrane in the rat uterus myocytes using potential sensitive fluorescent probe DiOC6(3). Ukr Biochem J. 2014; 86(1): 42-55. (In Ukrainian).

121. Elfering SL, Haynes VL, Traaseth NJ, Ettl A, Giulivi C. Aspects, mechanism, and biological relevance of mitochondrial protein nitration sustained by mitochondrial nitric oxide synthase. Am J Physiol Heart Circ Physiol. 2004; 286(1): H22-H29.

122. Crouser ED. Mitochondrial dysfunction in septic shock and multiple organ dysfunction syndrome. Mitochondrion. 2004; 4(5-6): 729741.

123. Brown GC. Nitric oxide and mitochondria. Front Biosci. 2007; 12: 1024-1033.

124. Akopova OV, Sagach VF. Effect of nitric oxide donors on $\mathrm{Ca}^{2+}$-uptake in the rat heart and liver mitochondria. Ukr Biokhim Zhurn. 2005; 77(2): 82-87. (In Russian).
125. Danylovych IuV, Kolomiiets' OV, Danylovych HV, Kosterin SO. Nitric oxide as a possible regulator of energy-dependent $\mathrm{Ca}^{2+}$ transport in mitochondria of uterine smooth muscle. Fiziol Zh. 2014; 60(2): 12-17. (In Ukrainian).

126. Akopova OV, Korkach IuP, Kotsiuruba AV, Kolchyns'ka LI, Sagach VF. Reactive nitrogen and oxygen species metabolism in rat heart mitochondria upon administration of $\mathrm{NO}$ donor in vivo. Fiziol Zh. 2012; 58(2): 3-15. (In Ukrainian).

127. A kopova OV, Kotsiuruba AV, Kharlamova OM, Korkach IuP, Sahach VF. The role of mitochondria in NO-dependent regulation of $\mathrm{Na}^{+}, \mathrm{K}^{+}$-ATP activity in the rat aorta. Fiziol $\mathrm{Zh}$. 2010; 56(4): 76-85. (In Ukrainian).

128. Beutner G, Sharma VK, Giovannucci DR, Yule DI, Sheu SS. Identification of a ryanodine receptor in rat heart mitochondria. $J$ Biol Chem. 2001; 276(24): 21482-21488.

129. Dedkova EN, Ji X, Lipsius SL, Blatter LA. Mitochondrial calcium uptake stimulates nitric oxide production in mitochondria of bovine vascular endothelial cells. Am J Physiol Cell Physiol. 2004; 286(2): C406-C415.

130. Yi M, Weaver D, Hajnóczky G. Control of mitochondrial motility and distribution by the calcium signal: a homeostatic circuit. J Cell Biol. 2004; 167(4): 661-672.

131. Bringold U, Ghafourifar P, Richter C. Peroxynitrite formed by mitochondrial NO synthase promotes mitochondrial $\mathrm{Ca}^{2+}$ release. Free Radic Biol Med. 2000; 29(3-4): 343-348.

132. Ghafourifar P, Schenk U, Klein SD, Richter C. Mitochondrial nitric-oxide synthase stimulation causes cytochrome $c$ release from isolated mitochondria. Evidence for intramitochondrial peroxynitrite formation. J Biol Chem. 1999; 274(44): 31185-31188.

Received 30.10.2017 